\title{
Perkembangan Tren Penelitian Kualitas Pelayanan Di Indonesia
}

\section{Development of Service Quality Research Trends in Indonesia Umar Reza Saputra, Endang Larasati, Tri Yuniningsih, Retno Sunu Astuti \& Teuku Afrizal*}

\author{
Departemen Administrasi Publik, Fakultas Ilmu Sosial dan Ilmu Politik, Universitas \\ Diponegoro, Semarang
}

Diterima: 22 Mei 2021 Direview: 22 Mei 2021; Disetujui: 14 Agustus 2021 *Coresponding Email : teukurian@lecturer.undip.ac.id

\begin{abstract}
Abstrak
Penelitian ini bertujuan untuk dapat memberikan gambaran terkait dengan perkembangan penelitian tentang kualitas pelayanan di Indonesia yang diambil jurnal terakreditasi Sinta 2 di Indonesia dan memberikan gambaran tentang konsep yang sering digunakan oleh peneliti di Indonesia sehingga dapat memunculkan kebaruan atau pengembangan tentang penelitian kualitas pelayanan yang beragam. Sampel yang digunakan adalah artikel tentang kualitas pelayanan dari tahun 2007 sampai dengan tahun 2020 yang membahas mengenai kualitas pelayanan. Metode dalam penelitian ini yaitu charting the field, merupakan teknik penelusuran untuk mengklasifikasikan artikel dengan kriteria yang ditetapkan yaitu berdasarkan metode penelitian, konten penelitian (variabel penelitian), sektor penelitian yang digunakan oleh peneliti di Indonesia. Hasil temuan diperoleh artikel sejumlah 167 yang terdapat dalam 29 jurnal terkareditasi Sinta 2 di indonesia yang telah memenuhi kriteria. Kemudian artikel diklasifikasikan berdasarkan metode penelitian, konten penelitian (variabel penelitian) dan sektor penelitian. Simpulan dari penelitian ini yaitu metode penelitian yang digunakan didominasi oleh metode kuantitatif. Variabel independen yang digunakan oleh peneliti tersebut didominasi oleh kualitas pelayanan. Variabel dependen didominasi oleh kepuasan pelanggan. Jurnal yang mendominasi penelitian mengenai kualitas pelayanan adalah Jurnal Aplikasi Manajemen. Penelitian tentang kualtias pelayanan Indonesia sebagian besar dilakukan pada sektor swasta.
\end{abstract}

Kata Kunci: Bibliografi; Literature Review; Metode Analitik; Charting The Field; Kualitas Pelayanan

\begin{abstract}
This study aims to be able to provide an overview related to the development of research on service quality in Indonesia taken by the accredited journal Sinta 2 in Indonesia and provide an overview of concepts that are often used by researchers in Indonesia so that they can bring up novelty or development of various service quality research. The sample used is an article on service quality from 2007 to 2020 which discusses service quality. The method in this study, charting the field, is a search technique for classifying articles with established criteria, namely based on research methods, research content (research variables), research sectors used by researchers in Indonesia. The findings obtained were 167 articles contained in 29 accredited journals of Sinta 2 in Indonesia that had met the criteria. Then the articles are classified based on the research method, research content (research variables) and research sector. The conclusion of this research is that the research method used is dominated by quantitative methods. The independent variable used by the researcher is dominated by service quality. The dependent variable is dominated by customer satisfaction. The journal that dominates research on service quality is the Journal of Management Applications. Research on the quality of service in Indonesia is mostly conducted in the private sector. Keywords: Bibliography; Literature Review; Analytical Methods; Charting The Field; Service quality
\end{abstract}

How to Cite: Saputra. U.R. Larasati, E. Yuninigsih, T., Astuti, R.S. \& Afrizal, T., (2021). Perkembangan Tren Penelitian Kualitas Pelayanan Di Indonesia. Journal of Education, Humaniora and Social Sciences (JEHSS). 4(2): 728-756. 


\section{PENDAHULUAN}

Kualitas pelayanan seringkali digunakan sebagai parameter oleh pelanggan sebagai penentu dari citra atau nilai suatu instansi lembaga (Sarmini, 2019). Dengan kata lain penyedia layanan harus selalu memperhatikan pelayanan yang diberikan demi menjaga kesan yang baik kepada pelanggan serta dalam penyelenggaraan pelayanan harus memperhatikan standar prosedur yang telah ditetapkan. Standar pelayanan diartikan sebagai acuan untuk dapat dijalankan oleh pemberi maupun penerima layanan atas kepastian dari proses layanan (Marlindawaty, 2020). Untuk dapat menyelanggarakan pelayanan yang baik sesuai dengan standar pelayanan yang ada, instansi ditutut untuk berkompeten dalam menjaga mutu pelayanan kepada pelanggan.

Sektor swasta sampai dengan sektor pemerintah pada saat ini terus memperhatikan kepuasan pelanggan untuk dapat menciptakan kualitas pelayanan. Berbagai strategi terus diupayakan untuk dapat menciptakan kualitas pelayanan terbaik untuk dapat memenangkan hati pelanggan. Hal tersebut tidaklah mudah dikarenakan pelanggan yang dihadapi sangat beragam. Namun tentu saja hal tersebut harus selalu diberikan layanan terbaik sehingga dapat menciptakan kepuasan pelanggan. Kepuasan pelanggan ditentukan oleh kualitas pelayanan yang diberikan (Prihastono, 2012).

Penelitian tentang kualitas pelayanan di Indonesia telah banyak dilakukan di Indonesia seperti yang dilakukan oleh (Fitriani, 2018), (Annisa, 2011), (Khusaeni, 2016), (Hermanto, 2013), (Risal, 2019), (Tiza \& Susanti, 2019), (Murdifin, 2020), dan (Marlius \& Ananda, 2020). Dari beberapa penelitian tersebut didapatkan hasil yang beragam dan menarik untuk diteliti kembali terkait dengan kualitas pelayanan. Mulai berkembangnya jurnal bidang manajemen, bisnis, pemerintah dan administrasi publik di Indonesia dengan pesat menjadikan peneliti untuk dapat mencoba mendokumentasikan dan mengevaluasi hasil penelitian tersebut dan meneliti lebih lanjut bagaimana perkembangan penelitian mengenai kualitas pelayanan di Indonesia dalam bentuk bibliografi.

Penelitian ini termotivasi dari penelitian yang dilakukan oleh (Dewi et al., 2018) yang mengkaji mengenai penelitian bibliografi perkembangan penelitian di bidang pengungkapan di Indonesia. Dalam penelitian ini, peneliti mencoba untuk mengakaji penelitian dalam bidang kualitas pelayanan di Indonesia dengan menggunakan metode yang sama dengan menggunakan 167 artikel yang tersebar dalam 29 jurnal terakreditasi Sinta 2 di bidang Manajemen, Bisnis, Administrasi Publik dan Pemerintahan di Indonesia selama periode 14 tahun 2007 sampai dengan 2020). Jurnal terakreditasi dipilih sebagai bahan pengamatan karena artikel yang dimuat dalam jurnal tersebut sebelumnya telah melewati seleksi yang ketat sehingga artikel yang diterbitkan memiliki kredibilitas dan kualitas yang baik. Penelitian ini menggunakan pendekatan "charting the field" dan "analyzing the community" yang digunakan untuk menganalisis dan memetakan perkembangan penelitian mengenai kualitas pelayanan selama kurun waktu 14 tahun terakhir dari beberapa jurnal terakreditasi di Indonesia.

Kontribusi dari penelitian ini yaitu pertama, mengklasifikasikan konten penelitian mengenai kualitas pelayanan berdasarkan sektor yang diteliti, variabel penelitian dan metode penelitian. Kedua, artikel ini memberikan gambaran kepada peneliti selanjutnya untuk dapat mengevaluasi dan menganalisis beberapa variabel, konten atau metode penelitian yang masih jarang dilakukan di Indonesia yang berkaitan dengan kualitas pelayanan.

\section{METODE PENELITIAN}

Metode yang digunakan dalam penelitian ini yaitu metode "charting the field". Metode ini merupakan metode yang dikembangkan oleh (Hesford et al., 2006) dan juga telah digunakan oleh peneliti di Indonesia seperti (Dewi et al., 2018) dan (Wigati et al., 2019). Metode "charting the field" ini adalah metode penelusuran untuk mengklasifikasikan artikel berdasarkan kriteria yaitu berdasarkan metode penelitian, konten penelitian (variabel penelitian), dan sektor penelitian. Dalam metode ini peneliti melakukan penelusuran artikel tentang kualitas pelayanan didalam 29 jurnal terakreditasi Sinta 2, kemudian dikelompokkan berdasarkan sektor penelitian (populasi), konten penelitian berdasarkan variabel penelitian dan metode penelitian. Sampel dalam 
penelitian ini dapat dilihat pada tabel 1. Pemilihan jurnal sebagai sampel dalam penelitian ini telah sesuai dengan kriteria yaitu: pertama, jurnal terakreditasi Sinta 2 tahun 2021. Kedua, jurnal tersebut dapat diakses secara online. Peneliti memilih secara terstruktur dan sistematis seluruh artikel yang diterbitkan disetiap jurnal tersebut. Ketiga, hanya memilih artikel yang terkait dengan kualitas pelayanan di Indonesia.

Tahap pemilihan sampel: pertama, peneliti mencari data mengenai jurnal terakreditasi Sinta 2 oleh DIKTI melalui website https://sinta.ristekbrin.go.id/journals? $\mathrm{q}=\&$ search $=1 \& \operatorname{sinta}=2$. Kedua, penelti membuka satu persatu jurnal dalam bidang manajemen, bisnis, administrasi publik dan pemerintahan. Ketiga, disetiap jurnal tersebut peneliti mengetik pada kolom search kata "kualitas pelayanan" atau "service quality", pada tahap ini setelah peneliti mengetik kata kunci tersebut dan jika tidak menemukan artikel yang terkait maka jurnal tersebut kamu keluarkan dari populasi yang awalnya 39 jurnal menjadi 29 jurnal. Keempat, peneliti mendownload setiap artikel yang terdapat pada jurnal tersebut. Kelima, peneliti mengklasifikasikan artikel kedalam tabulasi data berdasarkan judul, variabel, populasi dan sampel, hasil serta nama penulis dan tahun terbit.

Tabel 1. Daftar Nama Jurnal

\begin{tabular}{|c|c|c|c|}
\hline No & Nama Jurnal & Institusi & $\begin{array}{l}\text { Jumlah } \\
\text { Artikel }\end{array}$ \\
\hline 1 & Jurnal Bisnis dan manajemen & Universitas Padjajaran & 4 \\
\hline 2 & Jurnal manajemen dan Kewirausahaan & Univeritas Kristen Petra & 14 \\
\hline 3 & JAM: Jurnal Apliakasi Manajemen & Universitas Brawijaya & 33 \\
\hline 4 & Jurnal Manajemen Indonesia (JMI) & Universitas Telkom & 10 \\
\hline 5 & Mix: Jurnal Ilmiah Manajemen & Universitas Mercu Buana & 17 \\
\hline 6 & $\begin{array}{l}\text { JEMA: Jurnal Ilmiah Bidang Akuntansi dan } \\
\text { Manajemen }\end{array}$ & Universitas Islam Malang & 1 \\
\hline 7 & $\begin{array}{l}\text { Matrik: Jurnal Manajemen, Strategi Bisnis, dan } \\
\text { Kewirausahaan }\end{array}$ & Universitas Udayana & 6 \\
\hline 8 & $\begin{array}{l}\text { Matrik : Jurnal Manajemen, Teknik Informatika, dan } \\
\text { Rekayasa Komputer }\end{array}$ & Universitas Bumigora & 1 \\
\hline 9 & Jurnal Manajemen dan Pelayanan Farmasi & Universitas Gadjah Mada & 11 \\
\hline 10 & Jurnal Manajemen & Universitas Tarumanegara & 5 \\
\hline 11 & JDM (Jurnal Dinamika Manajemen) & Universitas Negeri Semarang & 7 \\
\hline 12 & Jurnal Aplikasi Bisnis dan Manajemen & Institut Pertanian Bogor & 3 \\
\hline 13 & $\begin{array}{l}\text { Industria: Jurnal Teknoloogi dan Manajemen } \\
\text { Agrooindustri }\end{array}$ & Univversitas Brawijaya & 2 \\
\hline 14 & Jurnal Manajemen \& Agribisnis & Institut Pertanian Bogor & 3 \\
\hline 15 & $\begin{array}{l}\text { Jurnal Manajemen Teknologi: Indonesian Journal for } \\
\text { the Science of Management }\end{array}$ & Institut Teknologi Bandung & 3 \\
\hline 16 & $\begin{array}{l}\text { JMMR (Jurnal Medicoeticolegal dan Manajemen } \\
\text { Rumah Sakit) }\end{array}$ & $\begin{array}{l}\text { Universitas } \quad \text { Muhammadiyah } \\
\text { Yogyakarta }\end{array}$ & 8 \\
\hline 17 & BISMA (Bisnis dan Manajemen) & Universitas Negeri Surabaya & 8 \\
\hline 18 & Jurnal Ekonomi dan Bisnis & Universitas Kristen Satya Wacana & 4 \\
\hline 19 & Jurnal Ilmiah Akuntansi dan Bisnis & Universitas Udayana & 1 \\
\hline 20 & IKONOMIKA: Jurnal Ekonomi dan Bisnis Islam & $\begin{array}{l}\text { Universitas Islam Negeri Raden } \\
\text { Intan Lampung }\end{array}$ & 1 \\
\hline 21 & Iqtishadia: Jurnal Kajian Ekonomi dan Bisnis Islam & STAIN Kudus & 4 \\
\hline 22 & JSINBIS: Jurnal Sistem Informasi Bisnis) & Universitas Diponegoro & 1 \\
\hline 23 & Jurnal Siasat Bisnis & Universitas Islam Indonesia & 5 \\
\hline 24 & $\begin{array}{l}\text { AdBispreneur: Jurnal Pemikiran dan Penelitian } \\
\text { Administrasi Bisnis dan Kewirausahaan }\end{array}$ & Universitas Padjajaran & 3 \\
\hline 25 & $\begin{array}{l}\text { Jurnal Pendidikan Ekonomi \& Bisnis (Edisi } \\
\text { Elektronik) }\end{array}$ & Universitas Negeri Jakarta & 3 \\
\hline
\end{tabular}




\begin{tabular}{llll}
\hline \multirow{2}{*}{ No } & Nama Jurnal & Institusi & $\begin{array}{c}\text { Jumlah } \\
\text { Artikel }\end{array}$ \\
\hline $\mathbf{2 6}$ & BISNIS \& BIROKRASI: Jurnal Ilmu Administrasi dan & Universitas Indonesia & 4 \\
& Organisasi & & \\
$\mathbf{2 7}$ & JKAP (Jurnal Kebijakan dan Administrasi Publik) & Universitas Gadjah Mada & $\mathbf{1}$ \\
$\mathbf{2 8}$ & Inovasi: jurnal Politik dan Kebijakan & Kementerian Dalam Negeri & $\mathbf{1}$ \\
$\mathbf{2 9}$ & Jurnal Studi Pemerintahan & Universitas Muhammadiyah & 3 \\
& & Yogyakarta & \\
\hline
\end{tabular}

\section{HASIL DAN PEMBAHASAN}

Hasil penelitian menunjukkan bahwa tren perkembangan penelitian tentang kualitas pelayanan sudah banyak dilakukan di Indonesia (lihat Gambar 1). Temuan selanjutnya yaitu mengenai metode penelitian yang digunakan yaitu metode kuantitatif, metode kualitatif, dan metode lainnya (lihat Gambar 2). Selanjutnya terkait dengan konten penelitian yang digunakan menunjukkan bahwa berdasarkan Variabel Indpenden, Variabel Dependen, Variabel intervening dan Variabel Moderating. Kemudian sektor penelitian diklasifikasikan pada sektor publik, sektor swasta dan lainnya (lihat Gambar 3).

Penelitian ini menggunakan artikel sejumlah 167 yang diperoleh dari 29 jurnal terkareditasi nasional Sinta 2 yang telah memenuhi kriteria. Adapun untuk setiap artikel yang digunakan dalam penelitian ini peneliti sajikan dalam tabel 2 berikut ini.

Tabel 2. Daftar Artikel Sampel

\begin{tabular}{|c|c|c|c|c|}
\hline No & $\begin{array}{l}\text { Nama } \\
\text { Jurnal }\end{array}$ & Judul & Nama Peneliti & Tahun \\
\hline 1 & JBM & $\begin{array}{l}\text { Consumers' Purchase Intention: Influencing Factors Unveiled } \\
\text { At Korean Thematic Café (Case Study: Chingu Café) }\end{array}$ & $\begin{array}{l}\text { Harimukti } \\
\text { Wandebori, } \\
\text { Vinon Wijaya }\end{array}$ & 2017 \\
\hline 2 & JBM & $\begin{array}{l}\text { The Influence Of Motivation On Quality Service Delivery In } \\
\text { Decentralised Indonesia }\end{array}$ & $\begin{array}{ll}\text { EDDY } & \text { S. } \\
\text { SOEGOTO }\end{array}$ & 2017 \\
\hline 3 & JBM & $\begin{array}{l}\text { The Influence Of National Health Insurance Members' Family } \\
\text { Satisfaction On Repurchasing Intention Of RSMC Hospital's } \\
\text { Inpatient Care Facility }\end{array}$ & $\begin{array}{l}\text { JOELIATY } \\
\text { NINUK } \\
\text { NURJAYANTI }\end{array}$ & 2018 \\
\hline 4 & JBM & $\begin{array}{l}\text { The Marketing Of Higher Education: Managing Student } \\
\text { Loyalty Based On Tuition Fee Policy And Service Quality }\end{array}$ & $\begin{array}{lr}\text { Yunia } & \text { Wardi, } \\
\text { Abror, } & \text { Okki } \\
\text { Trinanda } & \end{array}$ & 2018 \\
\hline 5 & JMK & $\begin{array}{l}\text { Analisa Kepuasan Senior Market Terhadap Kualitas Layanan } \\
\text { Di Hotel Bintang } 4 \text { Dan Bintang } 5 \text { Di Surabaya }\end{array}$ & $\begin{array}{l}\text { Maria } \\
\text { Tampubolon, } \\
\text { Perdani } \\
\text { Sukmaningrum }\end{array}$ & 2007 \\
\hline 6 & JMK & $\begin{array}{l}\text { Analisa Kesenjangan Kualitas Pelayanan Dan Kepuasan } \\
\text { Konsumen Pengunjung Plaza Tunjungan Surabaya }\end{array}$ & $\begin{array}{l}\text { Thomas Stefanus } \\
\text { Kaihatu }\end{array}$ & 2008 \\
\hline 7 & JMK & $\begin{array}{l}\text { The Influence Of The Morale And The Commitment Of } \\
\text { Administration Staff Towards The Organizational } \\
\text { Citizenship Behavior And Its Impact Towards Service Quality } \\
\text { Performance At Private Universities In Surabaya-Indonesia }\end{array}$ & $\begin{array}{l}\text { S. Pantja Djati } \\
\text { and Michael } \\
\text { Adiwijaya }\end{array}$ & 2009 \\
\hline 8 & JMK & $\begin{array}{l}\text { Pengaruh Kualitas Layanan, Kualitas Produk Dan Nilai } \\
\text { Nasabah Terhadap Kepuasan Dan Loyalitas Nasabah Bank } \\
\text { Mandiri }\end{array}$ & $\begin{array}{l}\text { Rachmad } \\
\text { Hidayat }\end{array}$ & 2009 \\
\hline 9 & JMK & $\begin{array}{l}\text { Analisis Komitmen (Affective, Continuance Dan Normative) } \\
\text { Terhadap Kualitas Pelayanan Pengesahan STNK Kendaraan } \\
\text { Bermotor (Studi Empiris Pada Kantor Bersama Samsat Di } \\
\text { Propinsi Kalimantan Timur) }\end{array}$ & Muchtar Hidayat & 2010 \\
\hline
\end{tabular}


Umar Reza Saputra, Endang Larasati, Tri Yuniningsih, \& Retno Sunu Astuti, Perkembangan Tren Penelitian

\begin{tabular}{|c|c|c|c|c|}
\hline No & $\begin{array}{l}\text { Nama } \\
\text { Jurnal }\end{array}$ & Judul & Nama Peneliti & Tahun \\
\hline 10 & JMK & $\begin{array}{l}\text { Korelasi Zone-Of-Tolerance Pada Service Quality Terhadap } \\
\text { Customer Value Di Pmk (Pemadam Kebakaran) Surabaya }\end{array}$ & $\begin{array}{l}\text { Diah } \\
\text { Dharmayanti } \\
\text { dan Zeplin Jiwa } \\
\text { Husada Tarigan }\end{array}$ & 2010 \\
\hline 11 & JMK & $\begin{array}{l}\text { Kualitas Layanan Dan Loyalitas Pasien (Studi Pada Rumah } \\
\text { Sakit Umum Swasta Di Kota Singaraja-Bali) }\end{array}$ & $\begin{array}{l}\text { Ketut Gunawan, } \\
\text { Sundring Pantja } \\
\text { Djati }\end{array}$ & 2011 \\
\hline 12 & JMK & $\begin{array}{l}\text { Analisis Konsekuensi Kualitas Pelayanan Tehadap Kepuasan } \\
\text { Masyarakat (Kajian Pada Pengguna Pelayanan Publik Dinas } \\
\text { Perhubungan \& LLAJ Provinsi Jawa Timur) }\end{array}$ & sukesi & 2011 \\
\hline 13 & JMK & $\begin{array}{l}\text { Pengaruh Market Orientation Terhadap Service Quality, } \\
\text { Satisfaction Dan Loyalty Pelanggan Toko Buku Gramedia Di } \\
\text { Jawa Timur }\end{array}$ & FX Agus Subroto & 2013 \\
\hline 14 & JMK & $\begin{array}{l}\text { Kepuasan Dan Loyalitas Konsumen Korporat Untuk Acara } \\
\text { Mice Terhadap Kualitas Pelayanan Hotel Hsth }\end{array}$ & Agus Prihanto & 2013 \\
\hline 15 & JMK & $\begin{array}{l}\text { The Influence Of Service Quality And Store Atmosphere On } \\
\text { Customer Satisfaction }\end{array}$ & $\begin{array}{l}\text { Miswanto, Yesi } \\
\text { Ria Angelia }\end{array}$ & 2017 \\
\hline 16 & JMK & $\begin{array}{l}\text { The Impact Of Total Quality Management On Service } \\
\text { Quality, Customer Engagement, And Customer Loyalty In } \\
\text { Banking }\end{array}$ & $\begin{array}{l}\text { Rosa Harimurti, } \\
\text { Tatik Suryani }\end{array}$ & 2019 \\
\hline 17 & JMK & $\begin{array}{l}\text { The Effect Of Service Quality, Perceived Value And } \\
\text { Mediating Effect Of Brand Image On Brand Trust }\end{array}$ & $\begin{array}{l}\text { Awalludin Fajar } \\
\text { Brata Wijaya, } \\
\text { Surachman, } \\
\text { Mugiono }\end{array}$ & 2020 \\
\hline 18 & JMK & $\begin{array}{l}\text { The determinant of web site quality and e-Service quality At } \\
\text { sme in indonesia }\end{array}$ & $\begin{array}{l}\text { Tatik Suryani, } \\
\text { Abu Amar Fauzi, } \\
\text { Moch. Nurhadi }\end{array}$ & 2020 \\
\hline 19 & JAM & $\begin{array}{l}\text { PENGARUH KUALITAS LAYANAN, ORIENTASI LAYANAN } \\
\text { DAN STRATEGI HARGA TERHADAP LOYALITAS } \\
\text { PELANGGAN (Studi Terhadap Pelanggan Jasa Transportasi } \\
\text { Kereta Api Eksekutif) }\end{array}$ & $\begin{array}{l}\text { Nova Retnowati, } \\
\text { Eka Afnan } \\
\text { Troena, Mintarti } \\
\text { Rahayu, } \\
\text { Munawar Ismail }\end{array}$ & 2008 \\
\hline 20 & JAM & $\begin{array}{l}\text { Pengaruh Citra, Reputasi Dan Kualitas Pelayanan Terhadap } \\
\text { Kepuasan Dan Loyalitas Mahasiswa PTS Di Jawa Timur } \\
\text { (Studi Pada STIE Dengan Program Studi Terkareditasi) }\end{array}$ & $\begin{array}{l}\text { Pribanus } \\
\text { Wantara }\end{array}$ & 2008 \\
\hline 21 & JAM & $\begin{array}{l}\text { Komitmen Manajemen, Pemasaran Internal, Kepuasan } \\
\text { Kerja Karyawan Dan Perilaku Positif Karyawan Dalam } \\
\text { Mempengaruhi Kualitas Pelayanan Rumah Sakit (Studi Pada } \\
\text { Rumah Sakit Tipe B Dan C Di Kalimantan Tengah) }\end{array}$ & Lelo Sintani & 2008 \\
\hline 22 & JAM & $\begin{array}{l}\text { Analisis Kepuasan Konsumen Terhadap Kualitas Pelayanan } \\
\text { Parkit Di Mega Mall A. Yani Pontianak }\end{array}$ & $\begin{array}{l}\text { Lidia chronika, } \\
\text { Lamria } \\
\text { Mangunsong, } \\
\text { Narsih }\end{array}$ & 2008 \\
\hline 23 & JAM & $\begin{array}{l}\text { Pengaruh Kualitas Pelayanan Terhadap Kepuasan Nasabah } \\
\text { Kredit Cepat Aman (KCA) (Studi Kasus Pada Perum } \\
\text { Pegadaian Di Makassar) }\end{array}$ & $\begin{array}{l}\text { Idayanti } \\
\text { Nursyamsi }\end{array}$ & 2008 \\
\hline 24 & JAM & $\begin{array}{l}\text { Pengaruh Kualitas Pelayanan Terhadap Kepuasan Wajib } \\
\text { Pajak Kendaraan Bermotor Di Kota Batu }\end{array}$ & $\begin{array}{l}\text { M. Khoiru } \\
\text { Rusydi, Fathoni }\end{array}$ & 2008 \\
\hline 25 & JAM & $\begin{array}{l}\text { Pengaruh Dimensi Servqual Terhadap Dimensi Kualitas } \\
\text { Relasional Serta Perannya Dalam Menimbulkan Niat Beli } \\
\text { Ulang Dan Loyalitas (Studi Pada Usaha Ritel Di Kota } \\
\text { Makassar) }\end{array}$ & $\begin{array}{l}\text { H. Baharuddin } \\
\text { Latief }\end{array}$ & 2012 \\
\hline
\end{tabular}


Vol 4, No. 2, November 2021: 728-756

\begin{tabular}{|c|c|c|c|c|}
\hline No & $\begin{array}{l}\text { Nama } \\
\text { Jurnal }\end{array}$ & Judul & Nama Peneliti & Tahun \\
\hline 26 & JAM & $\begin{array}{l}\text { Analisis Pengaruh Kualitas Pelayanan, Keadilan Dan } \\
\text { Kepuasan Nasabah Terhadap Loyalitas Nasabah Bank } \\
\text { Syariah (Studi Pada Nasabah Bank Syariah Di Propinsi Riau) }\end{array}$ & $\begin{array}{l}\text { Achmad Tavip } \\
\text { Junaedi, } \\
\text { Djumilah } \\
\text { Hadiwidjojo, Eka } \\
\text { Afnan Troena, } \\
\text { Iwan Triyuwono }\end{array}$ & 2012 \\
\hline 27 & JAM & $\begin{array}{l}\text { Pengaruh Service Quality Terhadap Loyalitas Dimediasi } \\
\text { Customer Value, Dan Customer Trust (Studi Pada Pengguna } \\
\text { Jasa PT Pos Indonesia Persero Malang 65100) }\end{array}$ & Suharto & 2012 \\
\hline 28 & JAM & $\begin{array}{l}\text { Pengaruh Kualitas Pelayanan Terhadap Loyalitas Debitur } \\
\text { Kredit Produktif (Studi Pada Kantor Cabang BNI SKC } \\
\text { Malang) }\end{array}$ & $\begin{array}{l}\text { I Wayan Jaman } \\
\text { Adi Putra }\end{array}$ & 2012 \\
\hline 29 & JAM & $\begin{array}{l}\text { Pengaruh Kualitas Pelayanan Terhadap Kepuasan, Nilai, } \\
\text { Kepercayaan Dan Loyalitas Pelanggan Rumah Tangga } \\
\text { (Perusahaan Daerah Air Minum Kota Kendari) }\end{array}$ & $\begin{array}{l}\text { Ishak } \\
\text { Awaluddin, } \\
\text { Margono } \\
\text { Setiawan }\end{array}$ & 2012 \\
\hline 30 & JAM & $\begin{array}{l}\text { Strategi Pemasaran Dan Kualitas Pelayanan Terhadap } \\
\text { Profitabilitas Usaha Koperasi Produksi Susu Peternakan }\end{array}$ & Alan Sugandi & 2013 \\
\hline 31 & JAM & $\begin{array}{l}\text { Pengaruh Kualitas Pelayanan Jasa Verifikasi Impor Terhadap } \\
\text { Kepuasan Dan Loyalitas Pelanggan Di PT Surveyor } \\
\text { Indonesia (Persero) }\end{array}$ & $\begin{array}{l}\text { Aliftia } \quad \text { Rizki } \\
\text { Annisa }\end{array}$ & 2014 \\
\hline 32 & JAM & $\begin{array}{l}\text { Analisis Faktor-Faktor Yang Mempengaruhi Kualitas } \\
\text { Pelayanan Karyawan Perusahaan Daerah Sulawesi Selatan }\end{array}$ & $\begin{array}{l}\text { M. Yahya, } \\
\text { Sapinah, } \\
\text { Suwardi Annas }\end{array}$ & 2014 \\
\hline 33 & JAM & $\begin{array}{l}\text { Analisis Pengaruh Kualitas Pelayanan Terhadap Kepuasan } \\
\text { Dan Loyalitas Pengguna Kawasan Industri }\end{array}$ & $\begin{array}{l}\text { Hendra } \\
\text { Lesmana, } \\
\text { Djumilah } \\
\text { Hadiwidjojo }\end{array}$ & 2014 \\
\hline 34 & JAM & $\begin{array}{l}\text { Peningkatan Kualitas Layanan Satu Pintu Di Kota Semarang } \\
\text { Dengan Penerapan Hard Skill Dan Soft Skill }\end{array}$ & $\begin{array}{l}\text { Tantri } \\
\text { Widiastuti Elma } \\
\text { Muncar Aditya } \\
\text { Ekayana } \\
\text { Sangkasari } \\
\text { Paranita }\end{array}$ & 2015 \\
\hline 35 & JAM & $\begin{array}{l}\text { Pengembangan Sumberdaya Manusia Dalam Meningkatkan } \\
\text { Kualitas Pelayanan Dan Kepuasan Pelanggan (Studi Pada } \\
\text { Aparatur Pemerintah Provinsi Kalimantan Timur) }\end{array}$ & $\begin{array}{l}\text { Syachrumsyah } \\
\text { Asri }\end{array}$ & 2015 \\
\hline 36 & JAM & $\begin{array}{l}\text { Pengaruh Kualitas Pelayanan Dan Biaya Terhadap Kepuasan } \\
\text { Dan Loyalitas Pasien RSUD Kota Bogor }\end{array}$ & $\begin{array}{l}\text { Adityawarman } \\
\text { Adil Muhammad } \\
\text { Syamsun } \\
\text { Mukhamad } \\
\text { Najib }\end{array}$ & 2016 \\
\hline 37 & JAM & $\begin{array}{l}\text { Hubungan Kualitas Pelayanan, Citra Sekolah, Kepuasan } \\
\text { Siswa Dan Loyalitas Siswa (Studi Empirik Di SMK Negeri } \\
\text { Rembang, Pasuruan, Jawa Timur) }\end{array}$ & A. Khusaeni & 2016 \\
\hline 38 & JAM & $\begin{array}{l}\text { Pengaruh Kualitas Kepuasan Dan Pelayanan Terhadap } \\
\text { Loyalitas Pengguna Kawasan Industri }\end{array}$ & Hendra Lesmana & 2016 \\
\hline 39 & JAM & $\begin{array}{l}\text { Customer Participation And Quality Of Service In Improving } \\
\text { Loyalty Visitors In Tourism Park }\end{array}$ & Sahnaz Ubud & 2017 \\
\hline 40 & JAM & $\begin{array}{l}\text { Analysis Of The Influence Of Excellent Service Training On } \\
\text { Inpatient Satisfaction In Rsia Puri Bunda Malang }\end{array}$ & $\begin{array}{l}\text { Kurnia } \\
\text { Widyaningrum, } \\
\text { Ahsan }\end{array}$ & 2017 \\
\hline
\end{tabular}

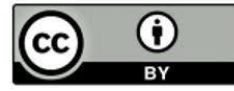


Umar Reza Saputra, Endang Larasati, Tri Yuniningsih, \& Retno Sunu Astuti, Perkembangan Tren Penelitian

\begin{tabular}{|c|c|c|c|c|}
\hline No & $\begin{array}{l}\text { Nama } \\
\text { Jurnal }\end{array}$ & Judul & Nama Peneliti & Tahun \\
\hline 41 & JAM & $\begin{array}{l}\text { The Effect Of Outpatient Pharmaceutical Service Quality On } \\
\text { Patient Loyalty Through Patient Satisfaction Of Karsa } \\
\text { Husada General Hospital Batu }\end{array}$ & $\begin{array}{lr}\text { Sapta } & \text { Dwi } \\
\text { Insani, Lukman } \\
\text { Hakim, Kurnia } \\
\text { Widyaningrum }\end{array}$ & 2017 \\
\hline 42 & JAM & $\begin{array}{l}\text { The Effect Of Service Quality On Outpatient Satisfaction Of } \\
\text { Dr. Soegiri General Hospital Lamongan }\end{array}$ & $\begin{array}{l}\text { Maya Dewi H, } \\
\text { Tita Hariyanti, A. } \\
\text { Rudijanto }\end{array}$ & 2017 \\
\hline 43 & JAM & $\begin{array}{l}\text { Effect Of Patient-Centered Care On Service Quality And } \\
\text { Satisfaction Level Of Bpjs Inpatients In Baptist Hospital Batu }\end{array}$ & $\begin{array}{l}\text { Estri Aditya } \\
\text { Pradani, Fatchur } \\
\text { Rohman, } \\
\text { Siswanto }\end{array}$ & 2018 \\
\hline 44 & JAM & $\begin{array}{l}\text { The Effect Of The Quality Of Pharmaceutical Service On } \\
\text { Outpatient Satisfaction Of Amelia Hospital }\end{array}$ & $\begin{array}{l}\text { Sahat Manampin } \\
\text { Siashsan, } \\
\text { Lukman Hakim, } \\
\text { Tita Hariyanti }\end{array}$ & 2018 \\
\hline 45 & JAM & $\begin{array}{l}\text { The Effect Of Service Quality On Customer Retention } \\
\text { Through Commitment And Satisfaction As Mediation } \\
\text { Variables In Java Eating Houses }\end{array}$ & $\begin{array}{l}\text { Sulva } \quad \text { Widya } \\
\text { Sari, } \quad \text { Sunaryo, } \\
\text { Mugiono }\end{array}$ & 2018 \\
\hline 46 & JAM & $\begin{array}{l}\text { The Strategy Of Improving Agritourism Service At Setiya Aji } \\
\text { Flower Farm By Using Ipa-Kano Approach }\end{array}$ & $\begin{array}{l}\text { Indah Arum } \\
\text { Ganestyani, } \\
\text { Jamhari, } \\
\text { Masyhuri }\end{array}$ & 2019 \\
\hline 47 & JAM & $\begin{array}{l}\text { The Influence Of Leadership Style On Service Quality In } \\
\text { Higher Education: A Study At A Social Science Faculty }\end{array}$ & $\begin{array}{l}\text { Andy Fefta } \\
\text { Wijaya, Catrine } \\
\text { Ana Prastyari, } \\
\text { Armanu }\end{array}$ & 2019 \\
\hline 48 & JAM & $\begin{array}{l}\text { Effect Of The Service Quality On Tutoring Customer's Word } \\
\text { Of Mouth And Satisfaction In Malang City }\end{array}$ & $\begin{array}{l}\text { Teresia Purnomo } \\
\text { Salim, Mintarti } \\
\text { Rahayu, } \\
\text { Sudjatno }\end{array}$ & 2019 \\
\hline 49 & JAM & $\begin{array}{l}\text { Customer Loyalty, Through Customer Satisfaction In } \\
\text { Customers Pt.Xyz }\end{array}$ & Liliana Dewi & 2020 \\
\hline 50 & JAM & $\begin{array}{l}\text { Building Consumer Satisfaction To Improve Consumer Trust } \\
\text { Through Service Quality And Consumer Experience In Jne } \\
\text { Pekanbaru }\end{array}$ & $\begin{array}{l}\text { A. Tavip Junaedi, } \\
\text { Evelyn Wijaya, } \\
\text { Megawati } \\
\text { Manullang }\end{array}$ & 2020 \\
\hline 51 & JAM & $\begin{array}{l}\text { The Role Of The Tourist Information Center (Tic) Of } \\
\text { Soekarno Hatta Airport In The Choice Of Tourist } \\
\text { Destinations Based On Tourist Characteristics And Services }\end{array}$ & $\begin{array}{l}\text { Agung Setiawan, } \\
\text { Jono M. } \\
\text { Munandar, } \\
\text { Ma'mun Sarma }\end{array}$ & 2020 \\
\hline 52 & JMI & $\begin{array}{l}\text { Pengaruh Empathy, Assurance Dan Responsiveness } \\
\text { Terhadap Kepuasan Nsabah PT. Pudential Life Assurance } \\
\text { Bandung }\end{array}$ & $\begin{array}{l}\text { Tjahjono } \\
\text { Djatmiko, } \\
\text { Carisshya } \\
\text { Habibah Sabrina }\end{array}$ & 2015 \\
\hline 53 & JMI & $\begin{array}{l}\text { Pengaruh Kualitas Pelayanan Terhadap Loyalitas Pelanggan } \\
\text { Pada Toko Buku Online Universitas Tebuka }\end{array}$ & $\begin{array}{l}\text { Minrohayati, } \\
\text { Meirani Harsasi, } \\
\text { Sri Lestari } \\
\text { Pujiastuti }\end{array}$ & 2016 \\
\hline 54 & JMI & $\begin{array}{l}\text { Electronic Service Quality On Mobile Application Of Online } \\
\text { Transportation Services }\end{array}$ & Abu Amar Fauzi & 2018 \\
\hline 55 & JMI & $\begin{array}{l}\text { Peran Kualitas Pelayanan Dan Kepuasan Pelanggan Dalam } \\
\text { Pembentukan Word Of Mouth Mahasiswa Perguruan Tinggi } \\
\text { Swasta Di Jakarta }\end{array}$ & Nani Fitriani & 2018 \\
\hline
\end{tabular}


Vol 4, No. 2, November 2021: 728-756

\begin{tabular}{|c|c|c|c|c|}
\hline No & $\begin{array}{l}\text { Nama } \\
\text { Jurnal }\end{array}$ & Judul & Nama Peneliti & Tahun \\
\hline 56 & JMI & $\begin{array}{l}\text { Loyalitas Pasien Rumah Sakit Pemerintah: Ditinjau Dari } \\
\text { Perspektif Kualitas Layanan, Citra, Nilai Dan Kepuasan }\end{array}$ & $\begin{array}{l}\text { Sabri Hasan, } \\
\text { Aditya Halim } \\
\text { Perdana Kusuma } \\
\text { Putra }\end{array}$ & 2018 \\
\hline 57 & JMI & $\begin{array}{l}\text { The Impact Of Service Quality And Brand Image Toward } \\
\text { Customer Loyalty In The Indonesian Airlines Industry }\end{array}$ & Nicholas Wilson & 2018 \\
\hline 58 & JMI & $\begin{array}{l}\text { Pengaruh Website Design Quality, Service Quality, Trust } \\
\text { Dan Satisfaction Terhadap Repurchase Intention (Studi } \\
\text { Kasus: Tokopedia.Com) }\end{array}$ & $\begin{array}{l}\text { Innocentius } \\
\text { Bernarto, } \\
\text { Nicholas Wilson, } \\
\text { Ian Nurpatria } \\
\text { Suryawan }\end{array}$ & 2019 \\
\hline 59 & JMI & $\begin{array}{l}\text { Factors Affecting Decisions To Choose Application Based } \\
\text { Transportation }\end{array}$ & $\begin{array}{l}\text { Nur Elfi Husda, } \\
\text { Nuramaliafitrah }\end{array}$ & 2020 \\
\hline 60 & JMI & $\begin{array}{l}\text { Predicting The Effects Of Perceived Service Quality And } \\
\text { Logistics Service Innovation On Repurchase Intention Of } \\
\text { Instant Courier Services Through Customer Satisfaction And } \\
\text { Trust }\end{array}$ & $\begin{array}{l}\text { Kunthi A. } \\
\text { Kusumawardani, } \\
\text { Saras } \quad \text { Asa } \\
\text { Hastayanti }\end{array}$ & 2020 \\
\hline 61 & JMI & $\begin{array}{l}\text { The Effect Of Online Learning Service Quality On Student } \\
\text { Satisfaction During Covidig Pandemic In } 2020\end{array}$ & $\begin{array}{l}\text { Hery Winoto } \mathrm{Tj} \text {, } \\
\text { Hans } \\
\text { Harischandra } \\
\text { Tanuraharjo }\end{array}$ & 2020 \\
\hline 62 & MIX & $\begin{array}{l}\text { Pengaruh Kualitas Produk Tabungan Dan Kualitas Layanan } \\
\text { Terhadap Minat Cimb } \\
\text { Di Menabung }\end{array}$ & Dedi Trisnadi & 2013 \\
\hline 63 & MIX & $\begin{array}{l}\text { Analisis Pengaruh Kualitas Pelayanan Terhadap Kepuasan } \\
\text { Penyewa Dalam Upaya Meningkatkan Loyalitas Penyewa } \\
\text { (Studi Kasus: Pt. Grand Indonesia) }\end{array}$ & Shelfy Indah R & 2014 \\
\hline 64 & MIX & $\begin{array}{l}\text { Analisis Pengaruh Citra Merek Dan Kualitas Layanan Service } \\
\text { Center Terhadap Loyalitas Pelanggan Melalui Kepuasan } \\
\text { Pelanggan (Studi Kasus: Nokia Care Center Wilayah Jakarta) }\end{array}$ & Gerry Sasongko & 2014 \\
\hline 65 & MIX & $\begin{array}{l}\text { Analisis Pengaruh Kualitas Produk, Distribusi Dan } \\
\text { Pelayanan Purna Jual Terhadap Kepuasan Pelanggan } \\
\text { Perusahaan Kemasan Plastik Pt. Jayatama Selaras }\end{array}$ & $\begin{array}{l}\text { Ignatius Herobe } \\
\text { Widyananto dan } \\
\text { Adi Nurmahdi }\end{array}$ & 2014 \\
\hline 66 & MIX & $\begin{array}{l}\text { Anteseden Dan Konsekwensi Dari Corporate Image Pada } \\
\text { Usaha Kecil Menengah / Ukm }\end{array}$ & $\begin{array}{l}\text { Sri Vandayuli } \\
\text { Riorini dan } \\
\text { Christina Catur } \\
\text { Widayati }\end{array}$ & 2014 \\
\hline 67 & MIX & 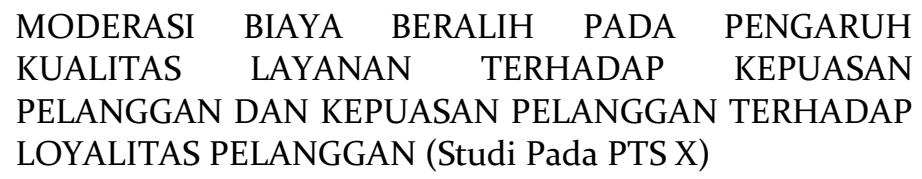 & $\begin{array}{l}\text { Hermansyah } \\
\text { Andi Wibowo }\end{array}$ & 2014 \\
\hline 68 & MIX & $\begin{array}{l}\text { Implementasi Strategi Peningkatan Loyalitas Pelanggan } \\
\text { Melalui Corporate Brand Equity, Product Atribute Dan } \\
\text { Service Quality Studi Kasus Pada Perusahaan Distribusi } \\
\text { Bahan Baku Bakery Dan Pastry Untuk Wilayah Pemasaran } \\
\text { Jakarta Dan Bandung }\end{array}$ & $\begin{array}{l}\text { Anik Tri } \\
\text { Suwarni, } \\
\text { Ardianto } \\
\text { Nugroho, } \\
\text { Nurlina Rahman }\end{array}$ & 2015 \\
\hline 69 & MIX & $\begin{array}{l}\text { Pengaruh Computer Self-Efficacy Terhadap Kualitas Sistem, } \\
\text { Kualitas Informasi, Kualitas Layanan, Penggunaan, } \\
\text { Kepuasan Pengguna, Dan Dampak Individu }\end{array}$ & $\begin{array}{l}\text { Suharno } \\
\text { Pawirosumarto, } \\
\text { Purwanto S. } \\
\text { Katidjan dan } \\
\text { Angga } \\
\text { Mulyanto }\end{array}$ & 2015 \\
\hline
\end{tabular}

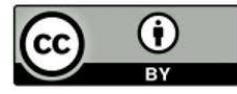


Umar Reza Saputra, Endang Larasati, Tri Yuniningsih, \& Retno Sunu Astuti, Perkembangan Tren Penelitian

\begin{tabular}{|c|c|c|c|c|}
\hline No & $\begin{array}{l}\text { Nama } \\
\text { Jurnal }\end{array}$ & Judul & Nama Peneliti & Tahun \\
\hline 70 & MIX & $\begin{array}{l}\text { Organizational Citizenship Behavior (Ocb), Service Quality, } \\
\text { And Patient Satisfaction: A Case Study Of The Nurses In } \\
\text { Private Hospitals Of Surabaya }\end{array}$ & $\begin{array}{l}\text { Thomas Stefanus } \\
\text { Kaihatu dan S. } \\
\text { Pantja Djati }\end{array}$ & 2016 \\
\hline 71 & MIX & $\begin{array}{l}\text { Service Quality Dan Kepuasan Konsumen: Studi Empiris } \\
\text { Dan Implikasinya Pada Toko Online }\end{array}$ & $\begin{array}{l}\text { Ari } \\
\text { Setiyaningrum } \\
\text { dan Herlin } \\
\text { Hidayat }\end{array}$ & 2016 \\
\hline 72 & MIX & $\begin{array}{l}\text { Pengaruh Persepsi Merek Jasa Terhadap Service Quality, } \\
\text { Value Dan Loyalitas Pelanggan: Studi Industri Low Cost } \\
\text { Airlines Indonesia }\end{array}$ & $\begin{array}{l}\text { Samuel } \\
\text { Pandhega, Sri } \\
\text { Rahayu Hijrah } \\
\text { Hati dan Savira } \\
\text { Miranti }\end{array}$ & 2016 \\
\hline 73 & MIX & $\begin{array}{l}\text { Pengaruh Kualitas Sistem, Kualitas Informasi, Dan Kualitas } \\
\text { Layanan Terhadap Kepuasan Pengguna Sistem E-Learning }\end{array}$ & $\begin{array}{l}\text { Suharno } \\
\text { Pawirosumarto }\end{array}$ & 2016 \\
\hline 74 & MIX & $\begin{array}{l}\text { The Influence Of Marketing Mix And Service Quality On } \\
\text { Corporate Reputation And Its Impact On Repurchase } \\
\text { Decision }\end{array}$ & $\begin{array}{l}\text { Aam Bastaman } \\
\text { and } \\
\text { Royyansyah }\end{array}$ & 2017 \\
\hline 75 & MIX & $\begin{array}{l}\text { Pengaruh Service Standard Communication Dan Komitmen } \\
\text { Manajemen Terhadap Kualitas Layanan Dan Kepuasan } \\
\text { Pelanggan }\end{array}$ & $\begin{array}{l}\text { Lulu Setiawati } \\
\text { dan Josephine } \\
\text { Kurniawati } \\
\text { Tjahjono }\end{array}$ & 2017 \\
\hline 76 & MIX & $\begin{array}{l}\text { Kepuasan Pelanggan Memediasi Pengaruh Kualitas } \\
\text { Pelayanan Dan Promosi Terhadap Loyalitas Pelanggan }\end{array}$ & $\begin{array}{l}\text { Novianti, Endri, } \\
\text { dan Darlius }\end{array}$ & 2018 \\
\hline 77 & MIX & $\begin{array}{l}\text { Passengers Perceptions Towards Service Quality Of Fsc Of An } \\
\text { Lcc Group }\end{array}$ & $\begin{array}{l}\text { Teguh I. } \\
\text { Maulana, Taufiq } \\
\text { Nur, dan Alvi } \\
\text { Muhayat Syah }\end{array}$ & 2018 \\
\hline 78 & MIX & $\begin{array}{l}\text { Pembentuk Word Of Mouth Pada Perusahaan Penerbangan } \\
\text { Bertarif Murah Di Indonesia }\end{array}$ & $\begin{array}{l}\text { Yasintha } \\
\text { Soelasih dan } \\
\text { Sumani }\end{array}$ & 2019 \\
\hline 79 & JEMA & $\begin{array}{l}\text { The Role Of Employee Motivation On The Relationship } \\
\text { Between Hrm Practices And Service Quality In Healthcare } \\
\text { Organization }\end{array}$ & Totok Sasongko & 2018 \\
\hline 80 & JMSBK & $\begin{array}{l}\text { Pengaruh Kualitas Layanan Terhadap Kepuasan Dan } \\
\text { Loyalitas Pelanggan Garuda Indonesia Di Denpasar }\end{array}$ & $\begin{array}{l}\text { A.A Ayu Atika } \\
\text { Paramitha } \\
\text { Wendha, I Ketut } \\
\text { Rahyuda, I Gst. } \\
\text { A. Kt. G. Suasana }\end{array}$ & 2013 \\
\hline 81 & JMSBK & $\begin{array}{l}\text { Pengaruh Kualitas Pelayanan Terhadap Kepuasan Dan } \\
\text { Loyalitas Pelanggan Tegal Sari Accommodation Di Ubud }\end{array}$ & $\begin{array}{l}\text { Ni Putu Sawitri, } \\
\text { Ni Nyoman Kert } \\
\text { Yasa, Abdulah } \\
\text { Jawas }\end{array}$ & 2013 \\
\hline 82 & JMSBK & $\begin{array}{l}\text { Pengaruh Kepuasan Kerja Terhadap } \\
\text { Organisasional Dan Kualitas Layanan }\end{array}$ & $\begin{array}{l}\text { Ni Made Dwi } \\
\text { Puspitawati, I } \\
\text { Gede Riana }\end{array}$ & 2014 \\
\hline 83 & JMSBK & $\begin{array}{l}\text { Membangun Kepuasan Nasabah Berbasis Dimensi Banking } \\
\text { Service Quality (Studi Bank Syariah Di Kabupaten Jember) }\end{array}$ & $\begin{array}{l}\text { Mohamad } \\
\text { Dimyati, } \\
\text { Mochammad } \\
\text { Farid Afandi, } \\
\text { Fajar Destari }\end{array}$ & 2020 \\
\hline 84 & JMSBK & $\begin{array}{l}\text { Membangun Loyalitas Pelanggan Berbasis E-Service Quality } \\
\text { Dengan Mediasi Kepuasan Pelanggan (Studi Pada } \\
\text { Transportasi Online Grabcar Di Kota Medan) }\end{array}$ & $\begin{array}{l}\text { Maya Sariı, } \\
\text { Muhammad } \\
\text { Andi Prayogi, } \\
\text { Jufrizen, }\end{array}$ & 2020 \\
\hline $7 \sqrt{760}$ & 8.11 & esainstitute.web.id/ojs2/index.php/jehss & tut@gmail.com & 36 \\
\hline
\end{tabular}




\begin{tabular}{|c|c|c|c|c|}
\hline No & $\begin{array}{l}\text { Nama } \\
\text { Jurnal }\end{array}$ & Judul & Nama Peneliti & Tahun \\
\hline 85 & JMSBK & $\begin{array}{l}\text { Interaksi E-Service Quality, Kesadaran Merek, Kepercayaan } \\
\text { Dan Kepuasan Terhadap Minat Pembelian Kembali Dalam } \\
\text { Transportasi On-Line Gojek }\end{array}$ & $\begin{array}{l}\text { Muhammad } \\
\text { Irfan Nasution } \\
\text { Ramadania, } \\
\text { Juniwati, Meilky } \\
\text { Limanto }\end{array}$ & 2020 \\
\hline 86 & $\begin{array}{l}\text { JMTIR } \\
\text { K }\end{array}$ & $\begin{array}{l}\text { Analisa Kepuasaan Pelanggan Dalam Layanan Jasa Travel } \\
\text { And Tour Pada Pt. Denar Pesona Menggunakan Metode } \\
\text { Fuzzy Servqual }\end{array}$ & $\begin{array}{l}\text { Nandang Iriadi, } \\
\text { Priatno, Putri } \\
\text { Agnes Sulistia }\end{array}$ & 2019 \\
\hline 87 & JMPF & $\begin{array}{l}\text { Analisis Persepsi Pelanggan Terhadap Penerapan Iso } \\
\text { 9001:200o Di Rumah Sakit Umum Pku Muhammadiyah } \\
\text { Bantul }\end{array}$ & $\begin{array}{l}\text { Cahyani } \\
\text { Hijriafitri, } \\
\text { Marchabab, } \\
\text { Sumami }\end{array}$ & 2011 \\
\hline 88 & JMPF & $\begin{array}{l}\text { Analisis Tingkat Kepuasan Pasien Rawat Jalan Terhadap } \\
\text { Kualitas Pelayanan Instalasi Farmasi Rsud Setjonegoro } \\
\text { Wonosobo }\end{array}$ & $\begin{array}{l}\text { Tiyas Putri } \\
\text { Nugraheni, } \\
\text { Achmad } \\
\text { Purnomo }\end{array}$ & 2011 \\
\hline 89 & JMPF & $\begin{array}{l}\text { Analisis Kepuasan Pasien Rawat Jalan Terhadap Kualitas } \\
\text { Pelayanan Farmasi Di Apotek X (Studi Pada Bulan } \\
\text { November 2011) }\end{array}$ & $\begin{array}{l}\text { Enggar } \\
\text { Anitawati, } \\
\text { Achmad } \\
\text { Fudholi, } \\
\text { Sumarni }\end{array}$ & 2012 \\
\hline 90 & JMPF & $\begin{array}{l}\text { Analisis Tingkat Kepuasan Pasien Rawat Jalan Atas Kualitas } \\
\text { Pelayanan Menggunakan Metode Servqual }\end{array}$ & $\begin{array}{l}\text { Widdy } \\
\text { Kurniawan } \\
\text { Santoso, } \\
\text { Marchaban, } \\
\text { Riswaka } \\
\text { Sudjaswadi }\end{array}$ & 2012 \\
\hline 91 & JMPF & $\begin{array}{l}\text { Pengaruh Kualitas Pelayanan Terhadap Kepuasan Dan } \\
\text { Loyalitas Pasien Rawat Inap: Kajian Empirik Rumah Sakit } \\
\text { Islam Fatimah Cilacap }\end{array}$ & $\begin{array}{l}\text { Zakki Kholid, } \\
\text { Suci } \\
\text { Paramithasari } \\
\text { Syahlani, Satibi }\end{array}$ & 2012 \\
\hline 92 & JMPF & $\begin{array}{l}\text { Analisis Kepuasan Pasien Farmasi Rawat Jalan } \\
\text { Menggunakan Metode Servqual: Studi Di Rumah Sakit } \\
\text { Swasta X Jakarta }\end{array}$ & $\begin{array}{l}\text { Daniar Pratiwi, } \\
\text { Djoko Wahyono, } \\
\text { Sampurno }\end{array}$ & 2013 \\
\hline 93 & JMPF & $\begin{array}{l}\text { Analisis Strategi Peningkatan Mutu Pelayanan Instalasi } \\
\text { Farmasi Rumah Sakit }\end{array}$ & $\begin{array}{l}\text { Naniek } \\
\text { Widyaningrum, } \\
\text { Sampurno, } \\
\text { Djoko Wahyono }\end{array}$ & 2013 \\
\hline 94 & JMPF & $\begin{array}{l}\text { Analisis Kualitas Layanan Sistem Informasi Manajemen } \\
\text { Farmasi Rumah Sakit Akademik Universitas Gadjah Mada }\end{array}$ & $\begin{array}{lr}\text { Arifin Santoso, } \\
\text { Hari Kusnanto, } \\
\text { M. } \\
\text { Lazuardi }\end{array}$ & 2013 \\
\hline 95 & JMPF & $\begin{array}{l}\text { Analisis Pengaruh Kualitas Pelayanan Pada Kepuasan Dan } \\
\text { Loyalitas Pelanggan Di Salon Dan Spa }\end{array}$ & $\begin{array}{lr}\text { Florensia } & \text { Kurnia } \\
\text { Puung, } & \text { A. } \\
\text { Fudholi, } & \text { Basu } \\
\text { Swastha } & \\
\text { Dharmesta } & \end{array}$ & 2014 \\
\hline 96 & JMPF & $\begin{array}{l}\text { Hubungan Kualitas Pelayanan Rawat Jalan Pada Era Jaminan } \\
\text { Kesehatan Nasional Terhadap Kepuasan Pasien }\end{array}$ & $\begin{array}{l}\text { Heru Nurcahyo, } \\
\text { Marchaban, } \\
\text { Sumarni }\end{array}$ & 2015 \\
\hline 97 & JMPF & $\begin{array}{l}\text { Pengaruh Tingkat Kualitas Pelayanan BPJS Dan } \\
\text { Karakteristik Pasien Terhadap Kepuasan Pasien Di Fasilitas } \\
\text { Kesehatan Tingkat Pertama }\end{array}$ & $\begin{array}{l}\text { Yogi Bhakti } \\
\text { Marhenta, Satibi, }\end{array}$ & 2018 \\
\hline
\end{tabular}


Umar Reza Saputra, Endang Larasati, Tri Yuniningsih, \& Retno Sunu Astuti, Perkembangan Tren Penelitian

\begin{tabular}{|c|c|c|c|c|}
\hline No & $\begin{array}{l}\text { Nama } \\
\text { Jurnal }\end{array}$ & Judul & Nama Peneliti & Tahun \\
\hline 98 & JM & $\begin{array}{l}\text { Analisis Kualitas Layanan Terhadap Kepuasan Konsumen } \\
\text { Pada Braja Mustika Hotel \& Convention Centre, Bogor }\end{array}$ & $\begin{array}{l}\text { Chairun } \\
\text { Wiedyaningsih } \\
\text { Stephanie } \\
\text { Alexandra } \\
\text { Suwanda dan } \\
\text { Edward Siregar }\end{array}$ & 2015 \\
\hline 99 & JM & $\begin{array}{l}\text { Pengaruh Kualitas Sistem, Kualitas Informasi, Dan Kualitas } \\
\text { Layanan Terhadap Penggunaan Sistem E-Learning Di } \\
\text { Program Pascasarjana Universitas Mercu Buana }\end{array}$ & $\begin{array}{l}\text { Purwanto S.K \& } \\
\text { Suharno } \\
\text { Pawirosumarto }\end{array}$ & 2017 \\
\hline 100 & JM & $\begin{array}{l}\text { Model Kepuasan Pelanggan: Analisis Kualitas Produk Dan } \\
\text { Kualitas Layanan Terhadap Citra Merek Pada Giant Citra } \\
\text { Raya Jakarta }\end{array}$ & $\begin{array}{l}\text { Agussalim M dan } \\
\text { Hapzi Ali }\end{array}$ & 2017 \\
\hline 101 & JM & $\begin{array}{l}\text { Peningkatan Tingkat Kepuasan Dosen Terhadap Kualitas } \\
\text { Pelayanan Pelatihan Jurnal Berkualitasmelalui Metode } \\
\text { Servqual }\end{array}$ & $\begin{array}{l}\text { Adhy Purnama } \\
\text { dan Ilah Sailah }\end{array}$ & 2017 \\
\hline 102 & $\mathrm{JM}$ & $\begin{array}{l}\text { The Effect Of Brand Image And Quality Of Educational } \\
\text { Services On Customer Satisfaction }\end{array}$ & $\begin{array}{l}\text { Connie } \\
\text { Chairunnisa }\end{array}$ & 2018 \\
\hline 103 & JDM & $\begin{array}{l}\text { Meningkatkah Kualitas Pelayanan Jasa Penerbangan } \\
\text { Indonesia Paska Insiden Kecelakaan Pesawat Terbang? }\end{array}$ & Arief Yulianto & 2010 \\
\hline 104 & JDM & $\begin{array}{l}\text { Kualitas Jasa Yang Mempengaruhi Loyalitas Dan } \\
\text { Relevansinya Terhadap Kepuasan }\end{array}$ & Siti Fatona & 2010 \\
\hline 105 & JDM & $\begin{array}{l}\text { Analisis Hubungan Kualitas Jasa Terhadap Kepuasan } \\
\text { Konsumen Pada Lembaga Pendidikan Kejuruan }\end{array}$ & Rintar & 2011 \\
\hline 106 & JDM & Kualitas Layanan Dan Positive Word Of Mouth & $\begin{array}{l}\text { Yulius Jatmiko } \\
\text { Nuryatno }\end{array}$ & 2012 \\
\hline 107 & JDM & $\begin{array}{l}\text { Mencapai Sumber Daya Manusia Unggul (Analisis Kinerja } \\
\text { Dan Kualitas Pelayanan) }\end{array}$ & Ketut Sudarma & 2012 \\
\hline 108 & JDM & Analysis Of Perceived Quality Of Education Service & Murwatiningsih & 2015 \\
\hline 109 & JDM & $\begin{array}{l}\text { The Effects Of Service Quality, Customer Satisfaction, Trust, } \\
\text { And Perceived Value Towards Customer Loyalty }\end{array}$ & $\begin{array}{l}\text { Tanisah, } \\
\text { Maftuhah }\end{array}$ & 2015 \\
\hline 110 & JABM & $\begin{array}{lllll}\text { Tingkat Kepuasan } & \text { Terhadap } & \text { Kualitas } & \text { Pelayanan } \\
\text { Pemeliharaan Data } & \text { Pendaftaran } & \text { Tanah } & \text { Di } & \text { Kantor } \\
\text { Pertanahan Kabupaten Bogor } & & & & \end{array}$ & $\begin{array}{l}\text { gawil } \\
\text { Despriyatmoko, } \\
\text { Rizal Syarief, } \\
\text { Agus Maulana }\end{array}$ & 2016 \\
\hline 111 & JABM & $\begin{array}{l}\text { Pengaruh Kualitas Layanan Perbankan Terhadap Kepuasan } \\
\text { Dan Loyalitas Nasabah Bank Syariah Xyz Di Jakarta }\end{array}$ & $\begin{array}{lr}\text { Hendri } & \text { Wijaya, } \\
\text { Irfan Syauqi Beik } \\
\text { dan } \quad \text { Bagus } \\
\text { Sartono }\end{array}$ & 2017 \\
\hline 112 & JABM & $\begin{array}{l}\text { Pengaruh Kualitas Pelayanan Lembaga Amil Zakat (Laz) } \\
\text { Terhadap Kepuasan Dan Loyalitas Muzakki (Studi Kasus Laz } \\
\text { Pkpu Yogyakarta) }\end{array}$ & $\begin{array}{l}\text { Sutomo, M. } \\
\text { Najib dan Setiadi } \\
\text { Djohar }\end{array}$ & 2017 \\
\hline 113 & $\begin{array}{l}\text { INDU } \\
\text { STRIA }\end{array}$ & $\begin{array}{l}\text { Analisis Perencanaan Strategi } \quad \text { Peningkatan } \\
\text { Kualitas Pelayanan Konsumen Dengan Metode } \\
\text { Quality Function Deployment (Qfd) }\end{array}$ & $\begin{array}{l}\text { Apriliya Putri R, } \\
\text { Usman Effendi, } \\
\text { Mas'ud Effendi }\end{array}$ & 2015 \\
\hline 114 & $\begin{array}{l}\text { INDU } \\
\text { STRIA }\end{array}$ & $\begin{array}{l}\text { Penilaian Kepuasan Konsumen Terhadap Kualitas } \\
\text { Pelayanan Menggunakan Metode Servqual (Service Quality) } \\
\text { Dan Six Sigma (Studi Kasus Pada "Restoran Dahlia" } \\
\text { Pasuruan) }\end{array}$ & $\begin{array}{lr}\text { Meryana } & \text { Santya } \\
\text { Paramita, } & \text { Wike } \\
\text { Agustin } & \text { Prima } \\
\text { Dania, } & \text { Dhita } \\
\text { Morita Ikasari }\end{array}$ & 2015 \\
\hline 115 & JMA & $\begin{array}{l}\text { Kepuasan Pelaku Usaha Terhadap Kualitas Layanan } \\
\text { Perizinan Pupuk Di Kementerian Pertanian }\end{array}$ & $\begin{array}{l}\text { Hasim Ashari, } \\
\text { Ujang Sumarwan } \\
\text { dan Kirbrandoko }\end{array}$ & 2013 \\
\hline
\end{tabular}


Vol 4, No. 2, November 2021: 728-756

\begin{tabular}{|c|c|c|c|c|}
\hline No & $\begin{array}{l}\text { Nama } \\
\text { Jurnal }\end{array}$ & Judul & Nama Peneliti & Tahun \\
\hline 116 & JMA & $\begin{array}{l}\text { Kualitas Jasa Unit Pelaksana Teknis Pengujian Sertifikasi } \\
\text { Mutu Barang-Lembaga Tembakau Jember }\end{array}$ & $\begin{array}{l}\text { Shinta Setiadevi, } \\
\text { Idqan Fahmi dan } \\
\text { Yossi Wibisono }\end{array}$ & 2014 \\
\hline 117 & JMA & $\begin{array}{l}\text { Pengaruh Service Quality, Product Quality Dan Perceived } \\
\text { Value Terhadap Kepuasan Dan Loyalitas Pelanggan Industri } \\
\text { Kayu Perhutani }\end{array}$ & $\begin{array}{l}\text { Winarni Saftarya } \\
\text { Timedina } \\
\text { Gultom, Lilik } \\
\text { Noor Yuliati, dan } \\
\text { Setiadi Djohar }\end{array}$ & 2016 \\
\hline 118 & JMT & $\begin{array}{l}\text { Peran Kualitas Produk Dan Layanan, Harga Dan Atmosfer } \\
\text { Rumah Makan Cepat Saji Terhadap Keputusan Pembelian } \\
\text { Dan Kepuasan Konsumen }\end{array}$ & Imam Santoso & 2016 \\
\hline 119 & JMT & $\begin{array}{l}\text { Pengembangan Model Evaluasi Kualitas Layanan Sistem E- } \\
\text { Government }\end{array}$ & $\begin{array}{l}\text { Rajestri } \\
\text { Govindaraju, } \\
\text { Iwan Intawan } \\
\text { Wiratmadja dan } \\
\text { Avif Haryana }\end{array}$ & 2016 \\
\hline 120 & JMT & $\begin{array}{l}\text { The Relationships Between Web Design, Reliability, Privacy, } \\
\text { Service Quality, And Purchase Intention Of Customers At E- } \\
\text { Commerce Business: An Empirical Study }\end{array}$ & $\begin{array}{lr}\text { Kevin Johan, } \\
\text { Wella Samantha, } \\
\text { Maria } \\
\text { Tandean, dan } \\
\text { Sabrina } \\
\text { Sihombing }\end{array}$ & 2020 \\
\hline 121 & JMMR & $\begin{array}{l}\text { Pengaruh Persepsi Produk Unggulan Dan Kualitas } \\
\text { Pelayanan Terhadap Loyalitas Pasien Poliklinik Bedah Di Rsi } \\
\text { Pku Muhammadiyah Pekajangan }\end{array}$ & $\begin{array}{l}\text { Susanto, } \\
\text { Rikhlatul Iffah }\end{array}$ & 2012 \\
\hline 122 & JMMR & $\begin{array}{l}\text { Persepsi Kepuasan Pasien Pada Kualitas Pelayanan Di } \\
\text { Rumah Sakit Gigi Dan Mulut Universitas Muhammadiyah } \\
\text { Yogyakarta }\end{array}$ & $\begin{array}{l}\text { Inna Sholihati } \\
\text { Embrik, Siti } \\
\text { Dyah Handayani } \\
\text { ' Mohammad } \\
\text { Syafril } \\
\text { Nusyirwan }\end{array}$ & 2013 \\
\hline 123 & JMMR & $\begin{array}{l}\text { Pengaruh Kualitas Jasa Pelayanan Terhadap Citra Instalasi } \\
\text { Radiologi Di Rumah Sakit Gigi Dan Mulut Pendidikan } \\
\text { Universitas Muhammadiyah Yogyakarta }\end{array}$ & $\begin{array}{l}\text { Shohibul Umam, } \\
\text { Siti Dyah } \\
\text { Handayani, } \\
\text { Qurratul Aini }\end{array}$ & 2014 \\
\hline 124 & JMMR & $\begin{array}{l}\text { PENGARUH KUALITAS PELAYANAN DAN HARGA } \\
\text { TERHADAP KEPUASAN PASIEN PADA KELAS VIP, 1, 2, } \\
\text { DAN } 3 \text { (Studi Pada RSU PKU Muhammadiyah Gamping } \\
\text { Yogyakarta) }\end{array}$ & $\begin{array}{l}\text { Virdy } \\
\text { Kurniawan, } \\
\text { Susanto }\end{array}$ & 2014 \\
\hline 125 & JMMR & $\begin{array}{l}\text { Evaluasi Kualitas Pelayanan Terhadap Kepuasan Pasien } \\
\text { Rawat Jalan Peserta Bpjs Di Rsud Panembahan Senopati } \\
\text { Bantul }\end{array}$ & $\begin{array}{l}\text { Fidela } \\
\text { Firdaus, } \\
\text { Dewi }\end{array}$ & 2015 \\
\hline 126 & JMMR & $\begin{array}{l}\text { Kualitas Pelayanan Kepuasan Pasien Rumah Sakit: Kasus } \\
\text { Pada Pasien Rawat Jalan }\end{array}$ & $\begin{array}{l}\text { Solichah } \\
\text { Supartiningsih }\end{array}$ & 2017 \\
\hline 127 & JMMR & $\begin{array}{l}\text { Implementation Of Case Management In Improving Quality } \\
\text { Of Service In Islamic Hospital Purwokerto (Case Study } \\
\text { Patient DM Type II) }\end{array}$ & Rini Indriana & 2018 \\
\hline 128 & JMMR & $\begin{array}{l}\text { The Analysis Of Inpatients Satisfaction On Service Quality } \\
\text { At Yogyakarta Respira Hospital }\end{array}$ & $\begin{array}{l}\text { Dahyanto, } \\
\text { Arofiati }\end{array}$ & 2018 \\
\hline 129 & BISMA & $\begin{array}{l}\text { Loyalitas Pelanggan : Pengaruh Kualitas Pelayanan Dan } \\
\text { Kepuasan Pelanggan Pada Rumah Sakit Umum Syaiful } \\
\text { Anwar Malang }\end{array}$ & $\begin{array}{l}\text { Prasetyo } \\
\text { Isbandono }\end{array}$ & 2009 \\
\hline
\end{tabular}

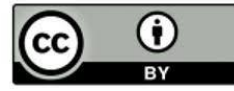




\begin{tabular}{|c|c|c|c|c|}
\hline No & $\begin{array}{l}\text { Nama } \\
\text { Jurnal }\end{array}$ & Judul & Nama Peneliti & Tahun \\
\hline 130 & BISMA & $\begin{array}{l}\text { Pengaruh Kualitas Layanan Jasa Terhadap Word Of Mouth } \\
\text { Dengan Kepuasan Pelanggan Sebagai Variabel Antara (Studi } \\
\text { Pada Biro Perjalanan Umum Rosalia Indah Surabaya) }\end{array}$ & $\begin{array}{l}\text { Deasy } \\
\text { Prameswari, } \\
\text { Anik Lestari }\end{array}$ & 2010 \\
\hline 131 & BISMA & $\begin{array}{l}\text { Pengaruh Pengelolaan Kualitas Layanan Melalui Program } \\
\text { Pertamina Way Terhadap Kepuasan Konsumen Dan } \\
\text { Dampaknya Pada Citra Spbu Pertamina (Studi Pada Spbu } \\
\text { Pasti Pas Di Surabaya) }\end{array}$ & $\begin{array}{l}\text { Sri Setyo Iriani, } \\
\text { Puguh Yulianto }\end{array}$ & 2010 \\
\hline 132 & BISMA & $\begin{array}{l}\text { PENGARUH KUALITAS LAYANAN } \\
\text { KEPUTUSAN PEMILIHAN TEMPAT PENDIDIKAN (Studi } \\
\text { Pada TK Raudlatul Jannah Pepelegi Waru - Sidoarjo) }\end{array}$ & $\begin{array}{l}\text { Indah } \\
\text { Rahmawati }\end{array}$ & 2012 \\
\hline 133 & BISMA & $\begin{array}{l}\text { Pengaruh Kualitas Layanan Terhadap Loyalitas Pelanggan } \\
\text { Melalui Kepuasan Pelanggan Sebagai Variabel Intervening } \\
\text { (Studi Pada Pelanggan Dunkin' Donuts Di Surabaya Dan } \\
\text { Sidoarjo) }\end{array}$ & $\begin{array}{l}\text { Kiki Amelia } \\
\text { Nurmala Dewi }\end{array}$ & 2016 \\
\hline 134 & BISMA & $\begin{array}{l}\text { Pengaruh Kualitas Pelayanan Terhadap } \\
\text { Pelanggan (Studi Orenztaxi) Di Surabaya }\end{array}$ & Noerchoidah & 2017 \\
\hline 135 & BISMA & $\begin{array}{l}\text { Peningkatan Perceived Customer Value Perumahan } \\
\text { Western Village Di Surabaya Melalui Penerapan Kualitas } \\
\text { Produk Dan Perceived Service Quality }\end{array}$ & $\begin{array}{l}\text { I Made Bagus D, } \\
\text { Pritarayu } \\
\text { Kusumawardhan } \\
\text { y }\end{array}$ & 2017 \\
\hline 136 & BISMA & $\begin{array}{l}\text { Peningkatan Perceived Customer Value Perumahan } \\
\text { Western Village Di Surabaya Melalui Penerapan Kualitas } \\
\text { Produk Dan Perceived Service Quality }\end{array}$ & $\begin{array}{l}\text { Santrianingrum } \\
\text { Soebandhi, } \\
\text { Abdul Wahid, Ira } \\
\text { Darmawanti }\end{array}$ & 2020 \\
\hline 137 & JEB & $\begin{array}{l}\text { Pengaruh Pemasaran Internal Dan Kualitas Layanan } \\
\text { Internal Terhadap Kepuasan Pelanggan Internal (Studi Pada } \\
\text { Industri Kepariwisataan Di Daerah Istimewa Yogyakarta) }\end{array}$ & Jumadi & 2014 \\
\hline 138 & JEB & $\begin{array}{l}\text { Analisis Swot Implementasi Teknologi Finansial Terhadap } \\
\text { Kualitas Layanan Perbankan Di Indonesia }\end{array}$ & $\begin{array}{l}\text { Imanuel Adhitya } \\
\text { Wulanata } \\
\text { Chrismastianto }\end{array}$ & 2017 \\
\hline 139 & JEB & $\begin{array}{l}\text { Kepatuhan Wajib Pajak Orang Pribadi: Studi Aspek } \\
\text { Pengetahuan, Kesadaran, Kualitas Layanan Dan Kebijakan } \\
\text { Sunset Policy }\end{array}$ & $\begin{array}{l}\text { Suyanto, Yhoga } \\
\text { Heru Pratama }\end{array}$ & 2018 \\
\hline 140 & JEB & $\begin{array}{l}\text { Price, Service Quality And Trust On Online Transportation } \\
\text { Towards Customer Satisfaction }\end{array}$ & $\begin{array}{ll}\text { Yusepaldo } & \\
\text { Pasharibu, } \\
\text { Eristia Lidia } \\
\text { Paramita, } \\
\text { Stefianus } & \\
\text { Febrianto } & \end{array}$ & 2018 \\
\hline 141 & JIAB & $\begin{array}{l}\text { Meningkatkan Kepatuhan Wajib Pajak Melalui Kualitas } \\
\text { Pelayanan }\end{array}$ & Ni Luh Supadmi & 2009 \\
\hline 142 & $\begin{array}{l}\text { IKON } \\
\text { OMIK } \\
\text { A }\end{array}$ & $\begin{array}{l}\text { Pengaruh Kualitas Pelayanan Dengan Kepuasan Konsumen } \\
\text { Pada Pt. Pusri Palembang Ppd Lampung }\end{array}$ & Yudiana Sari & 2016 \\
\hline 143 & $\begin{array}{l}\text { IQTIS } \\
\text { HADI } \\
\text { A }\end{array}$ & $\begin{array}{l}\text { Pengaruh Kualitas Pelayanan B2B Perbankan Syariah Dan } \\
\text { Cultural Fit Pada Kepuasan, Loyalitas Dan Rekomendasi } \\
\text { Positif }\end{array}$ & $\begin{array}{lr}\text { Tulus Haryono, } \\
\text { Hunik } & \text { Sri } \\
\text { Runing Sawitri, } \\
\text { MugiHarsono, } \\
\text { Ekawati Rahayu } \\
\text { Ningsih }\end{array}$ & 2016 \\
\hline 144 & $\begin{array}{l}\text { IQTIS } \\
\text { HADI } \\
\text { A }\end{array}$ & $\begin{array}{l}\text { Analisis Kepuasan Mahasiswa Stain Kudus Dalam Perspektif } \\
\text { Islam }\end{array}$ & Tina Martini & 2016 \\
\hline
\end{tabular}


Vol 4, No. 2, November 2021: 728-756

\begin{tabular}{|c|c|c|c|c|}
\hline No & $\begin{array}{l}\text { Nama } \\
\text { Jurnal }\end{array}$ & Judul & Nama Peneliti & Tahun \\
\hline 145 & $\begin{array}{l}\text { IQTIS } \\
\text { HADI } \\
\text { A }\end{array}$ & $\begin{array}{l}\text { Pengaruh Biaya, Angsuran Dan Kualitas } \\
\text { Terhadap Kepuasan Nasabah Pembiayaan } \\
\text { Kabupaten Kudus }\end{array}$ & $\begin{array}{l}\text { Wahibur } \\
\text { Rokhman }\end{array}$ & 2016 \\
\hline 146 & $\begin{array}{l}\text { IQTIS } \\
\text { HADI } \\
\text { A }\end{array}$ & $\begin{array}{l}\text { The Role Of Syariah Marketing In Increasing Customer } \\
\text { Loyalty (An Empirical Study Of BMT In Kudus Regency) }\end{array}$ & $\begin{array}{l}\text { Anita } \\
\text { Rahmawaty, } \\
\text { Wahibur } \\
\text { Rokhman }\end{array}$ & 2018 \\
\hline 147 & $\begin{array}{l}\text { JSINBI } \\
\text { S }\end{array}$ & $\begin{array}{l}\text { Analisis Kualitas Layanan E-Government Dengan } \\
\text { Pendekatan E-Govqual Modifikasi }\end{array}$ & $\begin{array}{l}\text { Frandika Septa, } \\
\text { Anton Yudhana, } \\
\text { Abdul Fadhil }\end{array}$ & 2019 \\
\hline 148 & JSB & $\begin{array}{l}\text { Analisis Asosiasi Merek, Nilai Produk, Dan Kualitas } \\
\text { Pelayanan, Serta Pengaruhnya Terhadap Kepuasan Dan } \\
\text { Loyalitas Konsumen Sepeda Motor Di Bekasi }\end{array}$ & $\begin{array}{l}\text { M. Rizan dan } \\
\text { Harum Arrasyid }\end{array}$ & 2008 \\
\hline 149 & JSB & $\begin{array}{l}\text { Pengaruh Kualitas Layanan Terhadap Kepatuhan Membayar } \\
\text { Pajak }\end{array}$ & Albari & 2009 \\
\hline 150 & JSB & $\begin{array}{l}\text { Pengaruh Kualitas Jasa Perguruan Tinggi Swasta Terhadap } \\
\text { Loyalitas Mahasiswa }\end{array}$ & Albari & 2009 \\
\hline 151 & JSB & $\begin{array}{l}\text { The Effects Of Role Stressors And Emotional Satisfaction On } \\
\text { Service Quality: Moderating Role Of Gender }\end{array}$ & $\begin{array}{l}\text { Handrio Adhi } \\
\text { Pradana dan } \\
\text { Hunik Sri } \\
\text { Runing Sawitri }\end{array}$ & 2015 \\
\hline 152 & JSB & $\begin{array}{l}\text { The Effect Of Online Service Quality And Consumers' } \\
\text { Motivation On Willingness To Participate In Co-Creation } \\
\text { Activities }\end{array}$ & $\begin{array}{l}\text { Agnes } \quad \text { Gracia } \\
\text { Quita, } \quad \text { Sahid } \\
\text { Susilo Nugroho }\end{array}$ & 2019 \\
\hline 153 & $\begin{array}{l}\text { AdBisp } \\
\text { reneur }\end{array}$ & $\begin{array}{l}\text { Pengaruh Variasi Produk, Kualitas Pelayanan, Harga Dan } \\
\text { Lokasi Terhadap Kepuasan Konsumen Pada Wedding } \\
\text { Organizer }\end{array}$ & Titik Efnita & 2017 \\
\hline 154 & $\begin{array}{l}\text { AdBisp } \\
\text { reneur }\end{array}$ & 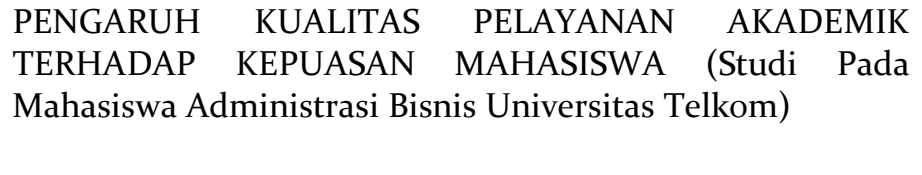 & $\begin{array}{l}\text { Vinny Jennifer } \\
\text { Rahareng, } \\
\text { Nurnida } \\
\text { Relawan }\end{array}$ & 2017 \\
\hline 155 & $\begin{array}{l}\text { AdBisp } \\
\text { reneur }\end{array}$ & $\begin{array}{l}\text { Aplikasi Importance Performance Analysis Dalam Menilai } \\
\text { Kualitas Pelayanan Jasa Pendidikan Di Propinsi Jawa Barat }\end{array}$ & $\begin{array}{l}\text { Deni Hamdani, } \\
\text { Saepudin, Ruddy } \\
\text { Rudolf Margo } \\
\text { Purnomo }\end{array}$ & 2019 \\
\hline 156 & JPEB & $\begin{array}{l}\text { Pengaruh Pengetahuan Anggota Tentang Koperasi Dan } \\
\text { Kualitas Pelayanan Terhadap Partisipasi Anggota Pada } \\
\text { Koperasi Serba Usaha (Ksu) Warga Sejahtera, Kelurahan } \\
\text { Cipinang, Jakarta Timur }\end{array}$ & $\begin{array}{l}\text { I Ketut R. } \\
\text { Sudiarditha, Ari } \\
\text { Saptono, Aprilia } \\
\text { Widyastuti }\end{array}$ & 2013 \\
\hline 157 & JPEB & $\begin{array}{l}\text { The Influence Cellular Provider Service Quality Towards } \\
\text { Customer Loyalty Indosat In Jakarta }\end{array}$ & Dita Puruwita & 2014 \\
\hline 158 & JPEB & $\begin{array}{l}\text { The Influence Services Quality, Promotion And Physical } \\
\text { Ecidence Against Customer Loyalty Cv. Funtatic Tour And } \\
\text { Travel }\end{array}$ & $\begin{array}{l}\text { Satria Aji } \\
\text { Gumelar, } \\
\text { Saparuddin M. }\end{array}$ & 2014 \\
\hline 159 & JBB & $\begin{array}{l}\text { Kualitas Pelayanan Publik Kecamatan Setelah } \\
\text { Perubahankedudukan Dan Fungsi Camat Sebagai Perangkat } \\
\text { Daerah }\end{array}$ & Rozy Afrial J. & 2009 \\
\hline 160 & JBB & $\begin{array}{l}\text { Pengaruh Kualitas Layanan Terhadap Kepuasan Pelanggan } \\
\text { Dalam Membentuk Loyalitas Pelanggan }\end{array}$ & $\begin{array}{l}\text { Dwi Aryani, } \\
\text { Febrina Rosinta }\end{array}$ & 2010 \\
\hline 161 & JBB & Pengaruh Remunerasi Terhadap Kualitas Pelayanan Publik & $\begin{array}{l}\text { Bambang } \\
\text { Sancoko }\end{array}$ & 2010 \\
\hline
\end{tabular}

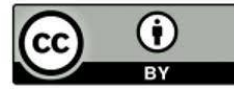


Umar Reza Saputra, Endang Larasati, Tri Yuniningsih, \& Retno Sunu Astuti, Perkembangan Tren Penelitian

\begin{tabular}{|c|c|c|c|c|}
\hline No & $\begin{array}{l}\text { Nama } \\
\text { Jurnal }\end{array}$ & Judul & Nama Peneliti & Tahun \\
\hline 162 & JBB & Analysis On Mobile Samsat's Public Service Quality & $\begin{array}{l}\text { Azhar Kasim, } \\
\text { Heri } \\
\text { Fathurahman }\end{array}$ & 2011 \\
\hline 163 & JKAP & $\begin{array}{l}\text { Implementasi Kebijakan Pembentukan Daerah Otonomi } \\
\text { Baru Dan Dampaknya Bagi Kualitas Pelayanan Publik }\end{array}$ & Daud M. Liando & 2012 \\
\hline 164 & $\begin{array}{l}\text { INOV } \\
\text { ASI }\end{array}$ & $\begin{array}{l}\text { Komunikasi Terapeutik Tenaga Kesehatan Terhadap Pasien } \\
\text { Rawat Inap Dalam Upaya Peningkatan Kualitas Pelayanan } \\
\text { Rumah Sakit Haji Medan }\end{array}$ & $\begin{array}{lr}\text { Nina } & \text { Siti } \\
\text { Salmania Siregar }\end{array}$ & 2020 \\
\hline 165 & JSP & $\begin{array}{l}\text { Kebijakan Reorganisasi Perizinan Untuk Meningkatkan } \\
\text { Kualitas Pelayanan Publik Di Kota Yogyakarta }\end{array}$ & Isnaini Muallidin & 2011 \\
\hline 166 & JSP & $\begin{array}{l}\text { Public Service Quality And Building Coordinated Policy: An } \\
\text { Analytical Study Of Jamkesmas And Jamkesda } \\
\text { Implementatio }\end{array}$ & $\begin{array}{ll}\text { Hevi } & \text { Kurnia } \\
\text { Hardini }\end{array}$ & 2013 \\
\hline 167 & JSP & $\begin{array}{l}\text { Influence Of Public Service Quality In Citizen Satisfaction } \\
\text { (Study In Private Hospital Y In Padang, West Sumatra } \\
\text { Province) }\end{array}$ & $\begin{array}{l}\text { Aldri Frinaldi, M. } \\
\text { Ali Embi }\end{array}$ & 2015 \\
\hline
\end{tabular}

Gambar 1. Trend Penelitian Kualitas Pelayanan di Indonesia

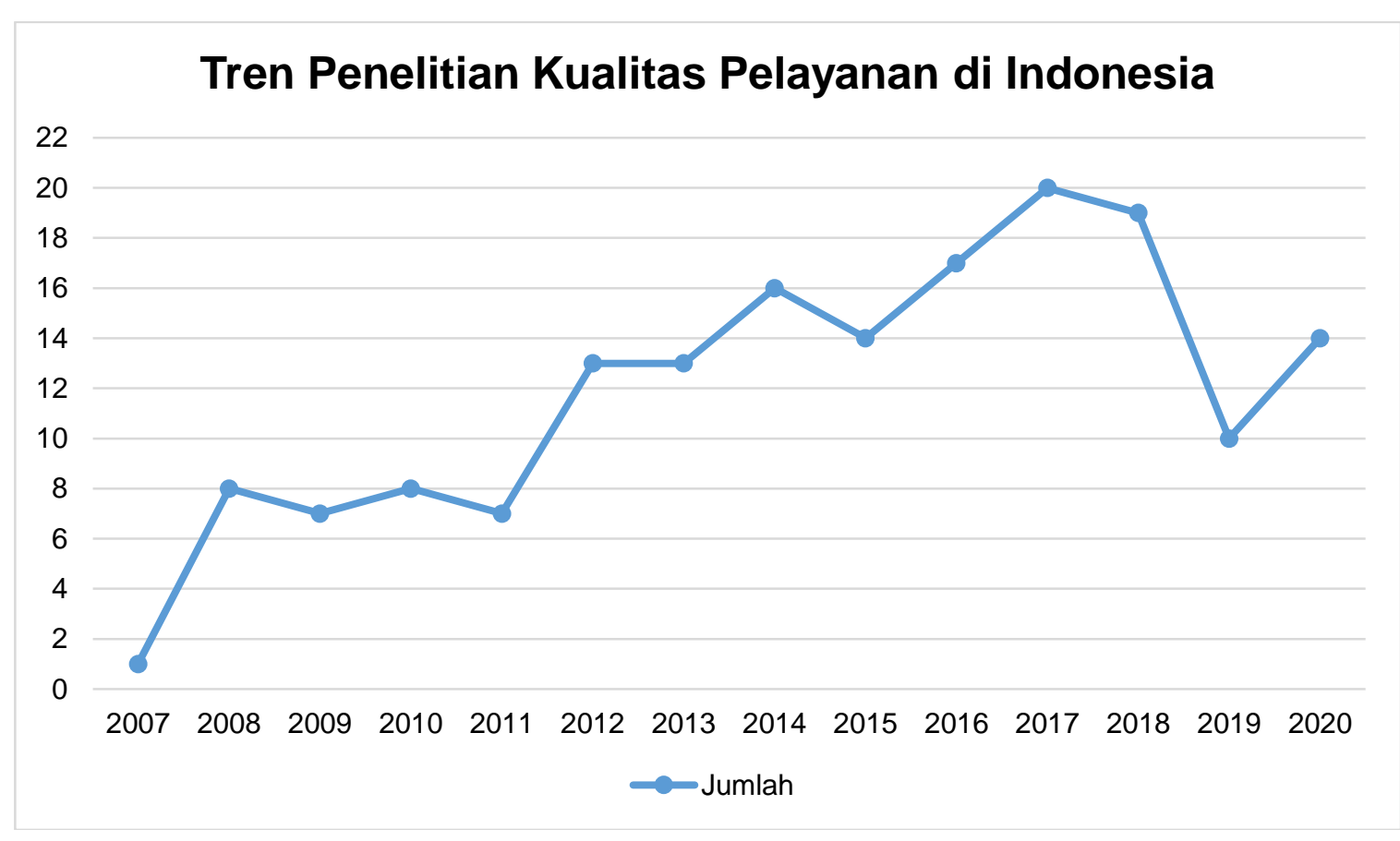

Penelitian ini dimulai dari tahun 2007 sampai dengan tahun 2020 atau selama periode 14 tahun dikarenakan dalam periode tersebut penelitian mengenai kualitas pelayanan di indonesia mulai berkembang dengan mengalami fluktuasi disetiap tahunnya. Dalam Gambar 1 terlihat bahwa pada tahun 2017 menjadi tahun dengan penelitian tentang kualitas pelayanan terbanyak yaitu dengan jumlah 20 artikel, disusul tahun 2018 dengan 19 artikel. Dan pada tahun 2007 yang dijadikan sebagai awal pengamatan terdapat artikel paling sedikit hanya terdapat 1 artikel saja. Peneliti melakukan klasifikasi artikel yang terdiri atas nama jurnal, judul artikel, nama peneliti, dan tahun publikasi. Artikel yang tidak tersedia secara online tidak kami masukan kedalam 
Vol 4, No. 2, November 2021: 728-756

pemilihan dikarenakan artikel yang kami gunakan yang tersedia secara online guna membantu peneliti dalam mengambil data.

Tabel 3. Deskripsi Sampel

\begin{tabular}{|c|c|c|c|c|c|c|}
\hline \multirow{2}{*}{ Nama Jurnal } & \multicolumn{2}{|c|}{2007 s/d 2020} & \multicolumn{2}{|c|}{2007 s/d 2013} & \multicolumn{2}{|c|}{2014 s/d 2020} \\
\hline & Jumlah & Presentase & Jumlah & Presentase & Jumlah & Presentase \\
\hline JBM & 4 & $2,40 \%$ & $\mathrm{o}$ & $0,00 \%$ & 4 & $3,64 \%$ \\
\hline JMK & 14 & $8,38 \%$ & 10 & $17,54 \%$ & 4 & $3,64 \%$ \\
\hline JAM & 33 & $19,76 \%$ & 12 & $21,05 \%$ & 21 & $19,09 \%$ \\
\hline JMI & 10 & $5,99 \%$ & o & o,oo\% & 10 & $9,09 \%$ \\
\hline MIX & 17 & $10,18 \%$ & 1 & $1,75 \%$ & 16 & $14,55 \%$ \\
\hline JEMA & 1 & $0,60 \%$ & o & $0,00 \%$ & 1 & $0,91 \%$ \\
\hline JMBK & 6 & $3,59 \%$ & 2 & $3,51 \%$ & 4 & $3,64 \%$ \\
\hline JMTIRK & 1 & $0,60 \%$ & o & $0,00 \%$ & 1 & $0,91 \%$ \\
\hline JMPF & 11 & $6,59 \%$ & 8 & $14,04 \%$ & 3 & $2,73 \%$ \\
\hline JM & 5 & $2,99 \%$ & $\mathrm{o}$ & o,oo\% & 5 & $4,55 \%$ \\
\hline JDM & 7 & $4,19 \%$ & 5 & $8,77 \%$ & 2 & $1,82 \%$ \\
\hline JABM & 3 & $1,80 \%$ & o & $0,00 \%$ & 3 & $2,73 \%$ \\
\hline INDUSTRIA & 2 & $1,20 \%$ & o & $0,00 \%$ & 2 & $1,82 \%$ \\
\hline JMA & 3 & $1,80 \%$ & 1 & $1,75 \%$ & 2 & $1,82 \%$ \\
\hline JMT & 3 & $1,80 \%$ & o & $0,00 \%$ & 3 & $2,73 \%$ \\
\hline JMMR & 8 & $4,79 \%$ & 2 & $3,51 \%$ & 6 & $5,45 \%$ \\
\hline BISMA & 8 & $4,79 \%$ & 4 & $7,02 \%$ & 4 & $3,64 \%$ \\
\hline JEB & 4 & $2,40 \%$ & o & $0,00 \%$ & 4 & $3,64 \%$ \\
\hline JIAB & 1 & $0,60 \%$ & 1 & $1,75 \%$ & o & $0,00 \%$ \\
\hline IKONOMIKA & 1 & $0,60 \%$ & o & $0,00 \%$ & 1 & $0,91 \%$ \\
\hline IQTISHADIA & 4 & $2,40 \%$ & o & o,oo\% & 4 & $3,64 \%$ \\
\hline JSINBIS & 1 & $0,60 \%$ & $\mathrm{o}$ & $0,00 \%$ & 1 & $0,91 \%$ \\
\hline JSB & 5 & $2,99 \%$ & 3 & $5,26 \%$ & 2 & $1,82 \%$ \\
\hline AdBISPRENEUR & 3 & $1,80 \%$ & o & $0,00 \%$ & 3 & $2,73 \%$ \\
\hline JPEB & 3 & $1,80 \%$ & 1 & $1,75 \%$ & 2 & $1,82 \%$ \\
\hline $\mathrm{JBB}$ & 4 & $2,40 \%$ & 4 & $7,02 \%$ & o & o,oo\% \\
\hline JKAP & 1 & $0,60 \%$ & 1 & $1,75 \%$ & o & $0,00 \%$ \\
\hline INOVASI & 1 & $0,60 \%$ & $\mathrm{o}$ & $0,00 \%$ & 1 & $0,91 \%$ \\
\hline JSP & 3 & $1,80 \%$ & 2 & $3,51 \%$ & 1 & $0,91 \%$ \\
\hline Total & 167 & $100 \%$ & 57 & $100,00 \%$ & 110 & $100,00 \%$ \\
\hline
\end{tabular}

Pada tabel 3 menunjukkan sampel yang digunakan dalam penelitian sesuai dengan periode yang ditentukan oleh peneliti yaitu tahun 2007 s/d 2020, ada satu jurnal yang sangat mendominasi dengan terdapat artikel tentang kualitas pelayanan yaitu JAM sebesar 19,76\%, selanjutnya diikuti oleh MIX sebesar 10,18\%, JMK sebesar 8,38\%, JMPF sebesar 6,59\%, JMI sebesar 5,99\%, JMR dan BISMA sebesar 4,79\%, JDM 4,19\%, MATRIK sebesar 3,59\%, JM dan JSB sebesar 2,99\%, sementara JBM, JEB, Iqtishadia dan JBB sebesar 2,40\%, berikutnya JABM, JMA, JMT, AdBispreneur, JPEB dan JSP sebesar 1,80\%, selenjutnya Industria sebesar 1,20\%, sementara JEMA, JMTIRK, JIAB, IKONOMIKA, JSINBIS, JKAP, INOVASI sebesar $0,60 \%$ atau hanya terdapat 1 artikel saja yang terkait dengan kualitas pelayanan.

Pada bagian tabel 3 juga terdapat perbandingan 2 periode, periode pertama yaitu antara periode 2007 s/d 2013 dan periode kedua tahun 2014 s/d 2020. Dalam tabel tersebut terlihat adanya peningkatan penelitian kualitas pelayanan dari 57 artikel penelitan menjadi 110 artikel penelitian. Peningkatan jumlah tersebut dipengaruhi oleh banyaknya peneliti melakukan penelitian tentang kualitas pelayanan kepada pelanggan yang hampir ada di semua Jurnal terkareditasi Sinta 2 tetang kualitas pelayanan atau service quality.

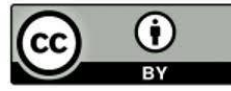




\section{Klasifikasi Artikel}

Dalam penelitian ini artikel di klasifikasi dengan berdasarkan metode penelitian, konten penelitian (variabel penelitian), dan sektor penelitian seperti yang telah dilakukan dalam penelitian (Dewi et al., 2018)

\section{Klasifikasi Artikel Berdasarkan Metode Penelitian}

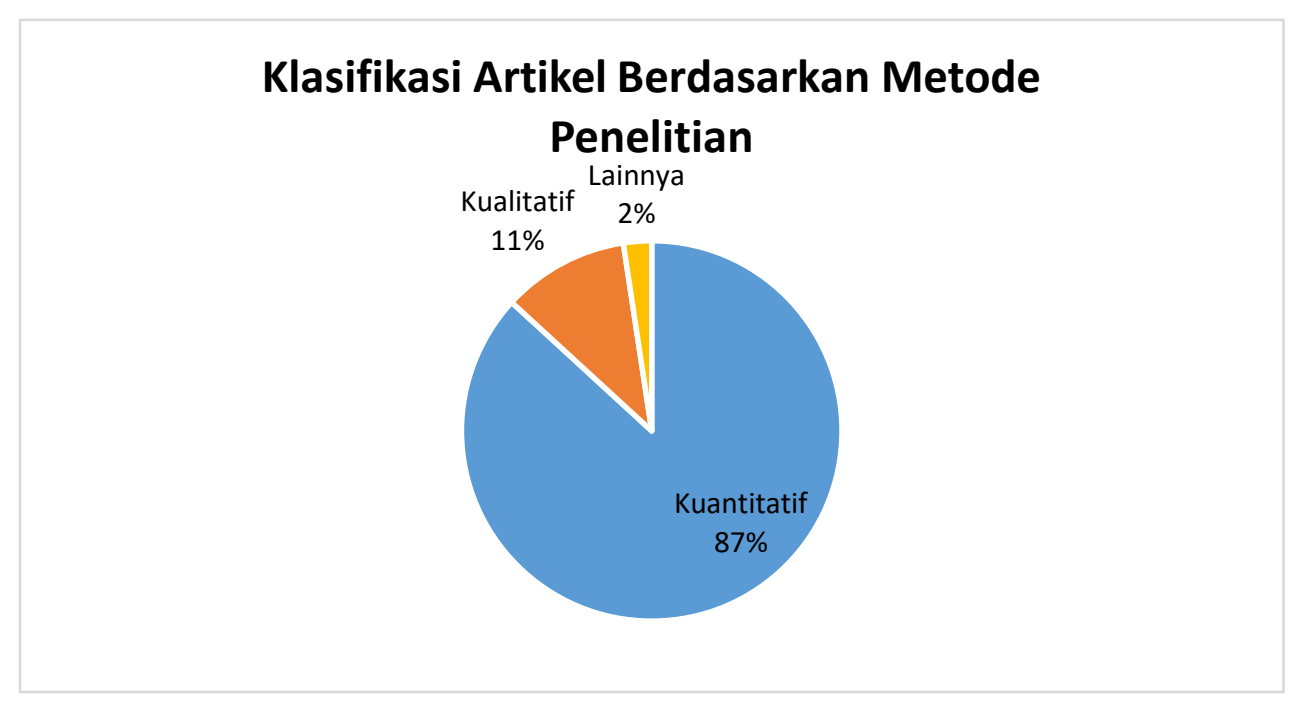

Gambar 2. Klasifikasi Artikel berdasarkan Metode Penelitian

Berdasarkan klasifikasi artikel pada gambar 2 tersebut dapat diketahui bahwa selama periode 2007 s/d 2020 penelitian tentang kualitas pelayanan di Indonesia paling banyak menggunakan metode kuantitatif sebesar $87 \%$ atau terdapat 145 artikel penelitian dari total artikel 167, kemudian metode kualitatif sebesar $11 \%$ atau terdapat 18 artikel penelitian dari total artikel 167, dan yang menggunakan metode lainnya sebesar $2 \%$ atau terdapat 4 artikel dari total artikel $167 \%$. Untuk metode lainnya didalamnya itu terdapat 3 artikel yang menggunakan mix method dan 1 artikel dengan metode six sigma.

\section{Klasifikasi berdasarkan Konten Penelitian}

Pengklasifikasian artikel tentang kualitas pelayanan di Indonesia dengan berdasarkan konten penelitan diklasifikasikan menjadi 4 yaitu variabel independen, variabel dependen, serta variabel Moderating dan variabel Intervening.

Tabel 4. Klasifikasi Variabel Independen

\begin{tabular}{lll}
\hline Variabel Independen & Jumlah & $\%$ \\
\hline Citra Merk & 6 & $3,17 \%$ \\
Kualitas Pelayanan & 94 & $49,74 \%$ \\
Aspek Pengetahuan & 1 & $0,53 \%$ \\
Kualitas Produk & 4 & $2,12 \%$ \\
Bauran Pemasaran & 1 & $0,53 \%$ \\
Reputasi & 1 & $0,53 \%$ \\
Dimensi kualitas pelayanan & 6 & $3,17 \%$ \\
gaya kepemimpinan & 2 & $1,06 \%$ \\
kepercayaan pelanggan & 4 & $2,12 \%$ \\
kepuasan kerja & 10 & $5,29 \%$ \\
kepuasan pelanggan & 15 & $7,94 \%$ \\
\hline
\end{tabular}

74tp://mahesainstitute.web.id/ojs2/index.php/jehss 
Vol 4, No. 2, November 2021: 728-756

\begin{tabular}{lll}
\hline Variabel Independen & Jumlah & $\%$ \\
\hline Kinerja & 2 & $1,06 \%$ \\
komitmen kerja & 4 & $2,12 \%$ \\
kompetensi karyawan & 1 & $0,53 \%$ \\
budaya organisasi & 1 & $0,53 \%$ \\
Komunikasi & 1 & $0,53 \%$ \\
kualitas interaksi & 1 & $0,53 \%$ \\
kualitas lingkungan fisik & 1 & $0,53 \%$ \\
culture fit & 1 & $0,53 \%$ \\
nilai pelanggan & 4 & $2,12 \%$ \\
loyalitas pelanggan & 3 & $1,59 \%$ \\
corporate image & 1 & $0,53 \%$ \\
Remunerasi & 4 & $2,12 \%$ \\
kualitas informasi & 2 & $1,06 \%$ \\
kualitas sistem & 3 & $1,59 \%$ \\
market orientation & 1 & $0,53 \%$ \\
organizational citizen behaviour & 1 & $0,53 \%$ \\
partisipasi pelanggan & 1 & $0,53 \%$ \\
pengembangan SDM & 1 & $0,53 \%$ \\
kualitas SDM & 1 & $0,53 \%$ \\
Perceived SERVQUAL & 1 & $0,53 \%$ \\
logistics service innovations & 1 & $0,53 \%$ \\
persepsi kualitas produk & 1 & $0,53 \%$ \\
persepsi kualitas pelayanan & 1 & $0,53 \%$ \\
role conflict & 1 & $0,53 \%$ \\
semangat kerja & 1 & $0,53 \%$ \\
strategi pemasaran & 1 & $0,53 \%$ \\
Total Quality Management & 1 & $0,53 \%$ \\
Zone of Tolerance & 1 & $0,53 \%$ \\
Variasi Produk & 1 & $0,53 \%$ \\
Web design & $100,00 \%$ \\
\hline Jumlah & 1 & \\
\hline & 1 & 1 \\
\hline
\end{tabular}

Tabel 4 menjelaskan secara detail mengenai variabel independen apasaja yang dibahas oleh peneliti. Secara keseluruhan, kualitas pelayanan menjadi paling dominan sebesar 49,74\%, kepuasan pelanggan sebesar 7,94\%, kepuasan kerja sebesar 5,29\%, sedangkan citra merk, dimensi kualitas pelayanan masing-masing sebesar 3,17\%. Untuk variabel kualitas produk, kepercayaan pelanggan, komitmen kerja, nilai pelanggan, remunerasi masing-masing sebesar 2,12\%, variabel loyalitas pelanggan dan kualitas sistem sebesar 1,59\%, variabel gaya kepemimpinan, kinerja, kualiatas informasi masing-masing sebesar 1,06\%. Sedangkan untuk variabel aspek pengetahuan, bauran pemasaran, reputasi, kompetensi karyawan, budaya organisasi, komunikasi, kualitas interaksi, kualitas lingkungan fisik, culture fit, corporate image, market orientation, organizational citizen behavior, partisipasi pelanggan, pengembangan SDM, kualitas SDM, Perceived SERVQUAL, logistics service innovations, persepsi kualitas produk, persepsi kualitas pelayanan, role conflict, semangat kerja, strategi pemasaran, Total Quality Management (TQM), Zone of Tolerance (ZOT), variasi produk, web design masing-masing sebesar 0,53\%.

Tabel 5. Klasifikasi Variabel Dependen

\begin{tabular}{lll}
\hline Variabel dependen & Jumlah & $\%$ \\
\hline Citra instansi & 3 & $1,51 \%$ \\
loyalitas pelanggan & 47 & $23,62 \%$ \\
kepuasan pelanggan & 76 & $38,19 \%$ \\
Harapan & 1 & $0,50 \%$ \\
kualitas pelayanan & 34 & $17,09 \%$ \\
\hline
\end{tabular}

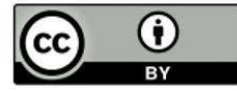


Umar Reza Saputra, Endang Larasati, Tri Yuniningsih, \& Retno Sunu Astuti, Perkembangan Tren Penelitian

\begin{tabular}{lll}
\hline Variabel dependen & Jumlah & $\%$ \\
\hline kepatuhan wajib pajak & 2 & $1,01 \%$ \\
Kepercayaan & 4 & $2,01 \%$ \\
Organizational Citizen Behaviour (OCB) & 1 & $0,50 \%$ \\
minat membeli kembali & 8 & $4,02 \%$ \\
Behavioral intension & 1 & $0,50 \%$ \\
komitmen organisasi & 2 & $1,01 \%$ \\
kualitas SDM & 1 & $0,50 \%$ \\
kualias sistem & 2 & $1,01 \%$ \\
kualitas informasi & 1 & $0,50 \%$ \\
Kinerja & 1 & $0,50 \%$ \\
partisipasi pelanggan & 1 & $0,50 \%$ \\
word of mouth & 5 & $2,51 \%$ \\
profitabilitas usaha & 1 & $0,50 \%$ \\
purchase intention & 3 & $1,51 \%$ \\
reputasi perusahaan & 1 & $0,50 \%$ \\
retensi pelanggan & 1 & $0,50 \%$ \\
Nilai & 3 & $1,51 \%$ \\
\hline Jumlah & $\mathbf{1 9 9}$ & $\mathbf{1 0 0} \% \mathbf{0 0} \%$ \\
\hline
\end{tabular}

Dilihat dari tabel 5 menunjukkan secara detail mengenai variabel dependen apasaja yang digunakan oleh peneliti. Dapat dilihat variabel yang paling dominan dalam penelitian tentang kualitas pelayanan adalah variabel kepuasan pelanggan sebesar 38,19\%. Kemudian diikuti oleh loyalitas pelanggan sebesar $23,62 \%$, kualitas pelayanan sebesar $17,09 \%$, minat membeli kembali sebesar 4,02\%, word of mouth sebesar 2,51\%, kepercayaan sebesar 2,01\%. Selanjutnya citra instansi, purchase intention, dan nilai masing-masing sebesar 1,51\%, untuk kepatuhan wajib pajak, komitmen organisasi, kualitas sistem masing-masing 1,01\%, sedangkan untuk harapan, organizational citizen behavior (OCB), behavioral intension, kualitas SDM, kualitas informasi, kinerja, partisipasi pelanggan, profitabilitas usaha, reputasi perusahaan dan retensi pelanggan masing-masing sebesar 0,50\%. Sehingga dapat disimpulkan bahwa peneliti di Indonesia tentang kualitas pelayanan pada variabel independen lebih banyak menggunakan kepuasan pelanggan, loyalitas pelanggan, dan kualitas pelayanan.

Tabel 6. Klasifikasi Variabel Intervening

\begin{tabular}{lll}
\hline Variabel Intervening & Jumlah & $\%$ \\
\hline Citra merk & 1 & $7,69 \%$ \\
Brand Trust & 1 & $7,69 \%$ \\
Corporate Brand Equity & 1 & $7,69 \%$ \\
Customer Value & 1 & $7,69 \%$ \\
Customer Trust & 1 & $7,69 \%$ \\
Kepuasan pelanggan & 5 & $38,46 \%$ \\
Kepercayaan pelanggan & 1 & $7,69 \%$ \\
Komitmen & 1 & $7,69 \%$ \\
Reputasi Perusahaan & 1 & $7,69 \%$ \\
\hline Total & 13 & $100,00 \%$ \\
\hline
\end{tabular}

Tabel 6 menunjukkan variabel intervening yang digunakan dalam penelitian tentang kualitas pelayanan oleh peneliti di Indonesia. Variabel intervening yang paling digunakan adalah kepuasan pelanggan sebesar 38,46\%, sedangkan untuk citra merk, brand trust, corporat brand equity, customer value, customer trust, kepercayaan pelanggan, komitmen dan reputasi perusahaan hanya terdapat 1 penelitian.

Tabel 7 menunjukkan variabel moderating yang digunakan dalam penelitian kualitas pelayanan di Indonesia. Variabel moderating kepuasan menjadi terbanyak yaitu sebesar $40 \%$ atau 
terdapat 2 penelitian, sedangkan untuk variabel biaya beralih, motivasi dan gender sebesar $20 \%$ atau hanya terdapat 1 penelitian.

Tabel 7. Klasifikasi Variabel Moderating

\begin{tabular}{lll}
\hline Variabel Intervening & Jumlah & $\%$ \\
\hline Biaya Beralih & 1 & $20,00 \%$ \\
Motivasi & 1 & $20,00 \%$ \\
Kepuasan & 2 & $40,00 \%$ \\
Gender & 1 & $20,00 \%$ \\
\hline & 5 & $100,00 \%$ \\
\hline
\end{tabular}

\section{Klasifikasi Sektor Penelitian Kualitas Pelayanan}

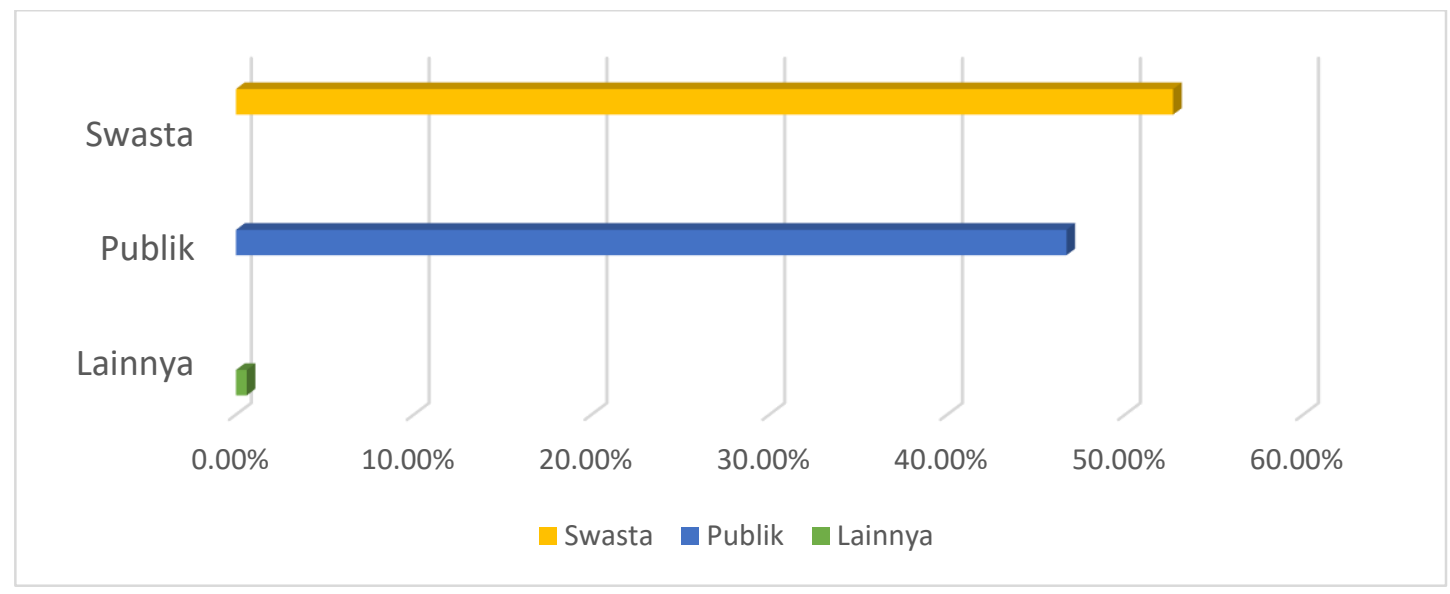

\section{Gambar 2. Sektor penelitian kualitas pelayanan}

Berdasarkan Gambar 2 menunjukkan sektor penelitian pada artikel tentang kualitas pelayanan didalam jurnal, sektor yang diminati oleh peneliti di Indonesia menunjukkan pada sektor swasta dengan jumlah sebesar 88 penelitian atau sekitar 52,69\%, kemudian penelitian sektor publik dengan jumlah penelitian sebesar 78 sekitar $46,71 \%$ dan penelitian lainnya hanya terdapat 1 penelitian deskriptif atau sekitar $0,60 \%$ yang tidak menyebutkan sektor penelitiannya. 


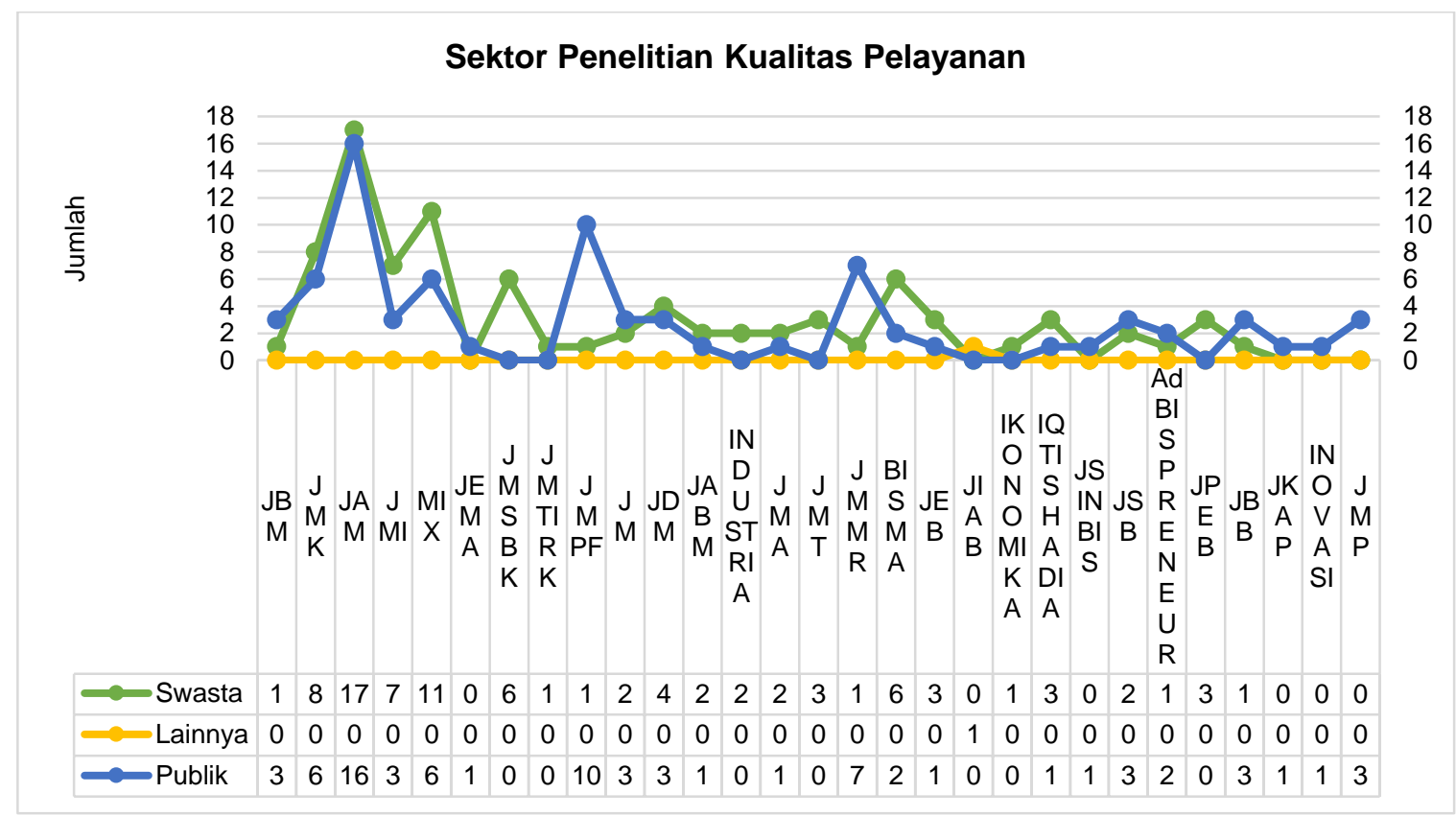

Gambar 3. Sektor penelitian berdasarkan jurnal publikasi

Dari 29 jurnal total artikel untuk sektor swasta sebanyak 88 artikel. Jurnal yang paling banyak menerbitkan artikel tersebut yaitu JAM sebanyak 17 artikel, selanjutnya MIX sebanyak 11 artikel, JMK sebanyak 8 artikel, JMI sebanyak 7 artikel, JMSBK dan BISMA sebanyak 6 artikel. Untuk JDM sebanyak 4 artikel, JMT, JEB, IQTISHADIA, JPEB masing-masing sebanyak 3 artikel, JM, JABM, INDUSTRIA, JMA, JSB masing-masing sebanyak 2 artikel, kemudian JBM, JMTIRK, JMPF, JMMR, IKONOMIKA, AdBISPRENEUR, JBB masing-masing sebnayak 1 artikel. Kemudian terdapat 6 jurnal yang tidak menerbitkan penelitian tentang kualitas pelayanan pada sektor swasta yaitu JEMA, JIAB, JSINBIS, JKAP, INOVASI, JMP.

Penelitian tentang kualitas pelayanan sektor publik total artikelnya sebanyak 78 artikel. Jurnal yang menerbitkan paling banyak yaitu JAM sebanyak 16 artikel. JMPF sebanyak 10 artikel, JMMR sebanyak 7 artikel, MIX, JMK sebanyak 6 artikel. Untuk Jurnal JBM, JMI, JM, JDM, JSB, JBB, JMP masing-masing sebanyak 3 artikel, BISMA, AdBISPRENEUR masing-masing sebanyak 2 artikel, JEMA, JABM, JMA, JEB, IQTISHADIA, JSINBIS, JKAP, INOVASI masing-masing 1 artikel. Kemudian, terdapat 7 Jurnal yang tidak menerbitkan penelitian kualitas pelayanan pada sektor publik yaitu JMSBK, JMTIRK, INDUSTRIA, JMT, JIAN, IKONOMIKA, dan JPEB. Sedangkan untuk lainnya merupakan penelitian menggunakan metode deskriptif (kualitatif) yang tidak menyebutkan instansi atau tidak menggunakan populasi penelitian sebanyak 1 artikel di jurnal JIAB.

Jurnal yang menerbitkan artikel tentang kualitas pelayanan di Indonesia pada sektor swasta terbanyak adalah JAM dengan 17 artikel, dan jurnal yang menerbitkan artikel tentang kualitas pelayanan pada sektor publik terbanyak adalah JAM sebanyak 16 artikel.

\section{SIMPULAN}

Dalam penelitian ini membahas artikel sebanyak 167 artikel tentang kualitas pelayanan di Indonesia yang diperoleh dari 29 Jurnal terakreditasi Sinta 2 di Indonesia yang diklasifikasikan berdasarkan metode penelitian, variabel penelitian, sektor penelitian yang diteliti. Metode penelitian yang digunakan didominasi oleh metode kuantitatif. Variabel independen yang digunakan oleh peneliti tersebut didominasi oleh kualitas pelayanan dan kepuasan pelanggan. Variabel dependen didominasi oleh kepuasan pelanggan, loyalitas pelanggan. Jurnal yang mendominasi penelitian mengenai kualitas pelayanan adalah JAM dan MIX. Penelitian tentang kualtias pelayanan Indonesia didominasi oleh sektor swasta, dengan tingkat presentase penelitian di Sektor Swasta. Penelitian selanjutnya diharapkan dapat melakukan penelitian berdasarkan 
konten atau variabel yang masih jarang untuk diteliti sehingga dapat terus mengembangkan penelitian tentang kualitas pelayanan yang lebih bervariasi.

\section{DAFTAR PUSTAKA}

Adil, A., Syamsun, M., \& Najib, M. (2016). Pengaruh Kualitas Pelayanan dan Biaya terhadap Kepuasan dan Loyalitas Pasien RSUD Kota Bogor. Jurnal Aplikasi Manajemen, 14(3), 432-441.

Albari. (2009). Pengaruh Kualitas Jasa Perguruan Tinggi Swasta Terhadap Loyalitas Mahasiswa. Jurnal Siasat Bisnis, 13(3), 203-215.

Albari. (2009). Pengaruh Kualitas Layanan Terhadap Kepatuhan Membayar Pajak. Jurnal Siasat Bisnis, 13(1), 113.

Anitawati, E., Fudholi, A., \& Sumarni. (2012). Analisis Kepuasan Pasien Rawat Jalan terhadap Kualitas Pelayanan Farmasi Di Apotek X (Studi pada Bulan November 2011). Jurnal Manajemen dan Pelayanan Farmasi, 2(2), 95-101.

Annisa, A. R. (2014). Pengaruh Kualitas Pelayanan Jasa Verifikasi Impor terhadap Kepuasan dan Loyalitas Pelanggan di PT. Surveyor Indonesia (Persero). Jurnal Aplikasi Manajemen, 12(1), 1-9.

Annisa, A. R. (2014). Pengaruh Kualitas Pelayanan Jasa Verifikasi Impor terhadap Kepuasan dan Loyalitas Pelanggan di PT. Surveyor Indonesia (Persero). Jurnal Aplikasi Manajemen, 12(1), 1-9.

Aryani, D., \& Rosinta, F. (2010). Pengaruh Kualitas Layanan terhadap Kepuasan Pelanggan dalam Membentuk Loyalitas Pelanggan. Bisnis \& Birokrasi, Jurnal Ilmiah Administrasi dan Organisasi, 17(2), 114-126.

Ashari, H., Sumarwan, U., \& Kirbrandoko. (2013). Kepuasan Pelaku Usaha terhadap Kualitas Layanan Perizinan Pupuk di Kementerian Pertanian. Jurnal Manajemen \& Agribisnis, 10(3), 156-164.

Asri, S. (2015). Pengembangan Sumberdaya Manusia dalam Meningkatkan Kualitas Pelayanan dan Kepuasan Pelanggan (Studi pada Aparatur Pemerintah Provinsi Kalimantan Timur). Jurnal Aplikasi Manajemen, 13(4), 662-672.

Awaluddin, I., \& Setiawan, M. (2012). Pengaruh Kualitas Pelayanan terhadap Kepuasan, Nilai, Kepercayaan dan Loyalitas Pelanggan Rumah Tangga (Perusahaan Daerah Air Minum Kota Kendari). Jurnal Aplikasi Manajemen, 10(4), 733-740.

Bastaman, A., \& Royyansyah, M. (2017). The Influence of Marketing Mix and Service Quality on Corporate Reputation and Its Impact on Repurchase Decision. Jurnal Mix, 7(2), 183-197.

Bernarto, I., Wilson, N., \& Suryawan, I. W. (2019). Pengaruh Website Design Quality, Service Quality, Trust dan Satisfaction terhadap Repurchase Intention (Studi Kasus tokopedia.com). Jurnal Manajemen Indonesia, 19(1), 80-90.

Chairunnisa, C. (2018). The Effect of Brand Image And Quality of Educational Services on Customer Satisfaction. Jurnal Manajemen, 22(3), 325-339.

Chrismantianto, I. A. (2017). Analisis SWOT Implementasi Teknologi Finansial terhadap Kualitas Layanan Perbankan di Indonesia. Jurnal Ekonomi dan Bisnis, 20(1), 133-144.

Chronika, L., Mangunsong, L., \& Narsih. (208). Analisis Kepuasan Konsumen Terhadap Kualitas Pelayanan Parkir di Mega Mall A. Yani Pontianak. Jurnal Aplikasi Manajemen, 7(4), 1018-1026.

D., I. M., \& Kusumawardhany, P. A. (2017). Peningkatan Perceived Customer Value Perumahan Western Village di Surabaya melalui Penerapan Kualitas Produk dan Perceived Service Quality. Jurnal Bisnis dan Manajemen, 10(1), 1-16.

Dahyanto, \& Arofiati, F. (2018). The Analysis of Inpatients Satisfaction on Service Quality at Yogyakarta Respira Hospital. Jurnal Madicoeticolegal dan Manajemen Rumah Sakit, 7(2), 162-169.

Despriyatmoko, G., Syarief, R., \& Maulana, A. (2016). Tingkat Kepuasan Terhadap Kualitas Pelayanan Pemeliharaan Data Pendaftaran Tanah diKantor Pertanahan Kabupaten Bogor. Jurnal Aplikasi Bisnis dan Manajemen, 2(2), 172-182.

Dewi, K. A. (2016). Pengaruh Kualitas Layanan terhadap Loyalitas Pelanggan melalui Kepuasan Pelanggan sebagai variabel Intervening (Studi Pada Pelanggan DUnkin'Donuts di Surabaya dan Sidoarjo). Jurnas Bisnis dan Manajemen, 9(1), 43-55.

Dewi, L. (2020). Customer Loyalty Through Customer Satisfaction in Customers PT.XYZ. Jurnal Aplikasi Manajemen, 18(1), 189-200.

Dharmayanti, D., \& Tarigan, Z. J. (2010). Korelasi Zone of Tolerance pada Service Quality terhadap Customer Value di PMK (Pemadan Kebakaran) Surabaya. Jurnal Manajemen dan Kewirausahaan, 12(2), 170-176.

Dimyati, M., Afandi, M. F., \& Destari , F. (2020). Membangun Kepuasan Nasabah berbasis Dimensi Banking Service Quality (Studi Bank Syariah di Kabupaten Jember0. Jurnal Manajemen Strategi Bisnis dan Kewirausahaan, 14(1), 112-124.

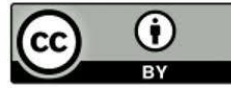


Djati, S. P., \& Adiwijaya, M. (2009). The Influence of The Morale and the Commitment of Administration Staff Towaeds the Organizational Citizenship Behavior and its Impact Towards Service Quality Performance at Private Universities in Surabaya-Indonesia. Jurnal Manajemen dan Kewirausahaan, 11(1), 20-30.

Djatmiko, T., \& Sabrina, C. H. (2015). Pengaruh Empathy Assurance dan Responsiveness terhadap Kepuasan Nasabah PT. Prudential Life Assrance Bandung. Jurnal Manajemen Indonesia, 15(2), 169-178.

Djatmiko, T., \& Sabrina, C. H. (2015). Pengaruh Empathy, Assurance dan Responsiveness terhadap Kepuasan Nasabah PT. Prudential Life Assurance Bandung. Jurnal Manajemen Indonesia, 15(2), 169-178.

Efnita, T. (2017). Pengaruh Variasi Produk Kualitas Pelayanan, Harga dan Lokasi terhadap Kepuasan Konsumen Pada Wedding Organizer. Jurnal AdBispreneur, 2(2), 107-115.

Embrik, I. S., Handayani, S. D., \& Nusyirwan, M. S. (2013). Persepsi Kepuasan Pasien Pada Kualitas Pelayanan di Rumah Sakit Gigi dan Mulut Universitas Muhammadiyah Yogyakarta. Jurnal Medicoeticolegal dan Manajemen Rumah Sakit, 2(1).

Fatona, S. (2010). Kualitas Jasa yang Mempengaruhi Loyalitas dan Relevansinya terhadap Kepuasan. Jurnal Dinamika Manajemen, 1(1), 41-46.

Fauzi, A. A. (2018). Electronic Service Quality on Mobile Application of Online Transportation Services. Jurnal Manajemen Indonesia, 18(1), 13-27.

Firdaus, F. F., \& Dewi, A. (2012). Evaluasi Kualitas Pelayanan terhadap Kepuasan Pasien Rawat Jalan Peserta BPJS di RSUD Panembahan Senopati Bantul. JMMR.

Fitriani, N. (2018). Peran Kualitas Pelayanan dan Kepuasan Pelanggan dalam Pembentukan Word of Mouth Mahasiswa Perguruan TInggi Swasta di Jakarta. Jurnal Manajemen Indonesia, 18(1), 40-51.

Frinaldi, A., \& Embi, M. A. (2015). Influence of Public Service Quality in Citizen Satisfaction (Study in Private Hospital Y in Padang, West Sumatra Province). Jurnal Studi Pemerintah, 6(1), 102-114.

Ganestani, I. A., Jamhari, \& Masyhuri. (2019). The Strategy of Improving Agritourism Service at Setiya Aji Flower Farm By Using IPA-KANO Approach. Jurnal Aplikasi Manajemen, 17(2), 217-226.

Govindaraju, R., Wiratmadja, I. I., \& Haryana, A. (2016). Pengembangan Model Evaluasi Kualitas Layanan Sistem E-Government. Jurnal Manajemen Teknologi, 15(2), 196-205.

Gultom, W. S., Yuliati, L. N., \& Djohar, S. (2016). Pengaruh Service Quality Product Quality dan Perceived Value terhadap Kepuasan dan Loyalitas Pelanggan Industri Kayu Perhutani. Jurnal Manajemen \& Agribisnis, 13(2), 109-121.

Gumelar, S. A., \& M. Saparuddin. (2014). The Influence Service Quality, Promotion and Physical Evidence Against Customer Loyalty CV. Funtastic Tour and Travel. Jurnal Pendidikan Ekonomi dan Bisnis, 2(1), $1-11$.

Gunawan, K., \& Djati, S. P. (2011). Kualitas Layanan dan Loyalitas Pasien (Studi pada Rumah Sakit Umum Swasta di Kota SIngaraja-Bali). Jurnal Manajemen dan Kewirausahaan, 13(1), 32-39.

Hamdani, D., Saepudin, Rudolf, R., \& Purnomo , M. (2018). Applicaton Importance Performance Analysis in Assessing the Quality of Education Services in West Java Provice. Jurnal AdBispreneur, 4(2), 157-170.

Hanggraningrum, M. D., Hariyanti, T., \& Rudijanto, A. (2017). The Effect of Service Quality on Outpatient Satisfaction of Dr. Soegiri General Hospital Lamongan. Jurnal Aplikasi Manajemen, 8(4), 643-650.

Hardini, H. K. (2013). Public Service Quality and Building Coordinated Policy: An Analytical Study of Jamkesmas and Jamkeda Implementation. Jurnal Studi Pemerintahan, 4(2), 278-290.

Harimurti, R., \& Suryani, T. (2019). The Impact of Total Quality Management on Service Quality Customer Engagment and Customer Loyality in Banking. Jurnal Manajemen dan Kewirausahaan, 21(2), 95-103.

Haryono, T., Sawitri, H. S., Harsono, M., \& Ningsih, E. R. (2016). Pengaruh Kualitas Pelayanan B2B Perbankan Syariah dan Cultural Fit pada Kepuasan Loyalitas dan Rekomendasi Positif. IQTISHADIA, 9(1), 53-80.

Hasan, S., \& Putra, A. H. (2018). Loyalitas Pasien Rumah Sakit Pemerintah: Ditinjau dari Perspektif Kualitas Layanan Citra Nilai dan Kepuasan. Jurnal Manajemen Indonesia, 18(3), 184-196.

Hermanto. (2013). Pengaruh Kualitas Pelayanan SDM Bank Syariah terhadap Kepuasan Nasabah: Studi pada BPRS Berkah Ramadhan. Jurnal Etikonomi, 12(1), 77-92.

Hesford, j. W., Lee, S.-H. S., Stede, W. A., \& Young, S. M. (2006). Management Accounting: A Bibliographic Study. Handbook of Management Accounting Reserarch, 1, 3-26.

Hidayat, M. (2010). Analisis Komitmen (Affective, Continuance dan Normative) terhadap Kualitas Pelayanan Pengesahan STNK Kendaraan Bermotor (Studi Empiris pada Kantor Bersama Samsat di Propinsi Kalimantan Timur). Jurnal Manajemen dan Kewirausahaan, 12(1), 11-23.

Hidayat, R. (2009). Pengaruh Kualitas Layanan, Kualitas Produk dan Nilai Nasabah Terhadap Kepuasan dan Loyalitas Nasabah Bank Mandiri. Jurnal Manajemen dan Kewirausahaan, 11(1), 59-72.

Hijriafitri, C., Marchaban, \& Sumarni. (2011). Analisis Persepsi Pelanggan terhadap Penerapan ISO 9001:2000 di Rumah Sakti Umum PKU Muhammadiyah Bantul. Jurnal Manajemen dan Pelayanan Farmasi, 1(2), 77 83. 
Husda, N. E., \& Nuramaliafitrah. (2020). Factors Affecting Decisions to Choose APplication Based Transportation. Jurnal Manajemen Indonesia, 20(2), 140-151.

Indrian, R. (2018). Implementation of Case Management in Improving Quality of Service in Islamic Hospital Purwokerto (Case Study Patient D< Tpe II). Jurnal Medicoeticolegal dan Manajemen Rumah Sakit), 7(2), 144-151.

Insani, S. D., Hakim , L., \& Widyaningrum, K. (2017). The Effect of Outpatient Pharmaceutical Service Quality on Patient Loyalty Through Patient Satisfaction of Karsa Husada General Hospital Batu. Jurnal Aplikasi Manajemen, 15(4), 616-623.

Iriadi, N., Priatno, \& Sulistia, P. A. (2019). Analisa Kepuasan Pelanggan dalam Layanan Jas Travel and Tour pada PT. Denar Pesona menggunakan metode Fuzzy SERVQUAL. Jurnal MATRIK, 18(2), 192-201.

Iriani, S. S., \& Yulianto, P. (2010). Pengaruh Pengelolaan Kualitas Layanan melalui Program Pertamina Way terhadap Kepuasan Konsumen dan Dampaknya Pada Citra SPBU Pertamina (Studi Pada SPBU Pasti Pas di Surabaya). Jurnal Bisnis dan Manajemen, 2(2), 107-120.

Isbandono, P. (2009). Loyalitas Pelanggan: Pengaruh Kualitas Pelayanan dan Kepuasan Pelanggan Pada Rumah Sakit Umum Syaiful Anwar Malang. Jurnal Bisnis dan Manajemen, 1(2), 131-139.

J., R. A. (2009). Kualitas Pelayanan Publik Kecamatan Setelah Perubahan Kedudukan dan Fungsi Camat Sebagai Perangkat Daerah. Bisnis \& Birokrasi, 16(2), 87-95.

Joeliaty, \& Nurjayanti, N. (2018). The Influence of National Health Insurance Member's Family Satisfaction on Repurchasing Intention of RSMC Hospital's Inpatient Care Facility. Jurnal Bisnis \& Manajemen, 19(1), 23-29.

Johan, K., Samantha, W., Tandean, M. T., \& Sihombing, S. O. (2020). The Relationship Between Web Design Reliability, Privacy, Service Quality, and Purchase intention of Customers at E-commerce Business: an Empirical Study. Jurnal Manajemen Teknologi, 19(1), 17-36.

Jumadi. (2014). Pengaruh Pemasaran Internal dan Kualitas Layanan Internal terhadap Kepuasan Pelanggan Internal (Studi pada Industri Kepariwisataan di Daerah Istimewa Yogyakarta). Jurnal Ekonomi Bisnis, 17(3), 1732.

Junaedi, A. T. (2012). Analisis Pengaruh Kualitas Pelayanan, Keadilan dan Kepuasan Nasabah terhadap Loyalitas Nasabah Bank Syariah (Studi pada Nasabah Bank Syariah di Propinsi Riau). Jurnal Aplikasi Manajemen, 10(1), 161-176.

Junaedi, A. T., Wijaya, E., \& manullang, M. (2020). Building Consumer Satisfaction to Improve Consumer Trust Through Service Quality and Consumer Experience in JNE Pekanbaru. Jurnal Aplikasi Manajemen, 18(3), 504-510.

Kaihatu, T. S. (2008). Analisa Kesenjangan Kualitas Pelayanan dan Kepuasan Konsumen Pengunjung Plaza Tunjungan Surabaya. Jurnal Manajemen dan Kewirausahaan, 10(1), 66-83.

Kaihatu, T. S., \& Djati, S. P. (2016). Organizational CItizenship Behavior (OCB), Service Quality and Patient Satisfaction: a Case Study of The Nurses In Private Hospitals of Surabaya. Jurnal MIX, 6(2), 213-227.

Kasim, A., \& Faturahman, H. (2011). Analysis on Mobile Samsat's Public Service Quality. Bisnis \& Birokrasi, Jurnal Ilmiah Administrasi dan Organisasi, 18(1), 22-32.

Kholid, Z., Syahlani, S. P., \& Satibi. (2012). Pengaruh Kualitas Pelayanan terhadap Kepuasan dan Loyalitas Pasien Rawat Inap: Kajian Empirik Rumah Sakit Islam Fatimah Cilacap. Jurnal Manajemen dan Pelayanan Farmasi, 2(4), 225-230.

Khusaeni, A. (2016). Hubungan Kualitas Pelayanan Citra Sekolah Kepuasan Siswa dan Loyalitas Siswa (Studi Empirik di SMK Negeri Rembang Pasuruan JATIM). Jurnal Aplikasi Manajemen, 14(4), 657-666.

Khusaeni, A. (2016). Hubungan Kualitas Pelayanan, Citra Sekolah, Kepuasan Siswa dan Loyalitas Siswa (Studi Empirik di SMK Negeri Rembang, Jawa Timur). Jurnal Aplikasi Manajemen, 14(4), 657-666.

Kurniawan, V., \& Susanto. (2014). Pengaruh Kualitas Pelayanan dan Harga terhadap Kepuasan Pasien pada Kelas VIP, 1,2,3 (Studi pada RSU PKU Muhammadiyah Gamping Yogyakarta). Jurnal Medicoetilegal, 3(2).

Kusumawaedani, K. A., \& Hastayanti, S. A. (2020). Predicting the Effects of Perceived Service Quality and Logistics Servicce Innovation on Repurchase Intention of Instant Courier Services through Customer Satisfaction and Trust. Jurnal Manajemen Indonesia, 20(3), 177-193.

Latief, H. B. (2012). Pengaruh Dimensi Servqual terhadap Dimensi Kualitas Relasional serta Perannya dalam Menimbulkan Niat Beli Ulang dan Loyalitas (Studi pada Usaha Ritel di Kota Makassar). Jurnal Aplikasi Manajemen, 10(1), 142-151.

Lesmana, H. (2016). Pengaruh Kualitas Kepuasan dan Pelayanan terhadap Loyalitas Pengguna Kawasan Industri. Jurnal Aplikasi Manajemen, 14(4), 788-801.

Lesmana, H., \& Hadiwidjojo, D. (2014). Analisis Pengaruh Kualitas Pelayanan terhadap Kepuasan dan Loyalitas Pengguna Kawasan Industri. Jurnal Aplikasi Manajemen, 12(2), 222-229.

Liando, D. M. (n.d.). Implementasi Kebijakan Pembentukan Daerah Otonomi Baru dan Dampaknya Bagi Kualitas Pelayanan Publik. Jurnal Kebijakan dan Administrasi Publik.

http://mahesainstitute.web.id/ojs2/index.php/jehss nahesainstitut@gmail.com

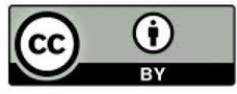

This work is licensed under a Creative Commons Attribution 4. 
M., A., \& Ali, H. (2017). Model Kepuasan Pelanggan: Analisis Kualitas Produk dan Kualitas Layanan terhadap Citra Merek pada Giant Citra Raya Jakarta. Jurnal Manajemen, 21(3), 317-335.

Marhenta, Y. B., Satibi, \& Wiedyaningsih, C. (2018). Pengaruh Tingkat Kualitas Pelayanan BPJS dan Karakteristik Pasien terhadap Kepuasan Pasien di Fasilitas KEsehatan Tingkat Pertama. Jurnal Manajemen dan Pelayanan Farmasi, 8(1), 18-23.

Marlindawaty. (2020). Kualitas Pelayanan Administrasi Publik di Kelurahan Sepinggan Raya Kota Balikpapan. Jurnal GeoEkonomi, 11(2), 229-240.

Marlius, D., \& Ananda, F. (2019). Pengaruh Kualitas Pelayanan Website Akademik terhadap Minat Kuliah di AKBP Padang. Jurnal Pundi, 3(3), 191-204.

Martini, T. (2016). Analisis Kepuasan Mahasiswa STAIN Kudus dalam Perspektif Islam. IQTISHADIA, 9(1), 8198.

Maulana, T. I., Nur, T., \& Syah, A. M. (2018). Passengers Perceptions Towards Service Quality of FSC of an LCC Group. Jurnal MIX, 8(3), 449-462.

Minrohayati, Harsasi, M., \& Pujiastuti, S. L. (2016). Pengaruh Kualitas Pelayanan terhadap Loyalitas Pelanggan pada Toko Buku Online Universitas Terbuka. Jurnal Manajemen Indonesia, 16(3), 155-162.

Miswanto, \& Angelia, Y. R. (2017). The Influence of Service Quality and Store Atmosphere on Customer Satisfaction. Jurnal Manajemen dan Kewirausahaan, 19(2), 106-111.

Muallidin, I. (2011). Kebijakan Reorganisasi Perijinan Untuk Meningkatkan Kualitas Pelayanan Publik di Kota Yogyakarta. Jurnal Studi Pemerintahan, 2(2), 398-423.

Murdifin, I. (2020). Pengaruh Kualitas Pelayanan terhadap Kepuasan Nasabah pada PT. Bank Danamon Cabang Makassar. Jurnal Equilibrium, 1(2), 23-33.

Murwatiningsih. (2015). Analysis of Perceived Quality of Education Service. Jurnal Dinamika Manajemen, 6(1), 40-54.

Nierchoidah. (2017). Pengaruh Kualitas Pelayanan terhadap Kepuasan Pelanggan (Studi Orenztaxi) di Surabaya. Jurnal Bisnis dan Manajemen, 9(2), 80-90.

Novianti, Endri, \& Darlius. (2018). Kepuasan pelanggan memediasi Pengaruh kualitas pelayanan dan Promosi terhadap Loyalitas Pelanggan. Jurnal MIX, 8(1), 90-108.

Nugrahenil, T. P., \& Purnomo, A. (2011). Analisis Tingkat Kepuasan Pasien Rawat Jalan Terhadap Kualtas Pelayanan Instalasi Farmasi RSUD Setjonegoro Wonosobo. Jurnal Manajemen dan Pelayanan Farmasi, 1(2), 118-125.

Nurcahyo, H., Marchaban, \& Sumarni. (2015). Hubungan Kualitas Pelayanan Rawat Jalan Pada Era Jaminan Kesehatan Nasional terhadap Kepuasan Pasien. Jurnal Manajemen dan Pelayanan Farmasi, 5(2), $104-$ 108.

Nursyamsi, I. (2008). Pengaruh Kualitas Pelayanan Terhadap Kepuasan Nasabah Kredit Cepat Aman (KCA) (Studi Kasus pada Perum Pegadaian di Makassar). Jurnal Aplikasi Manajemen, 7(3), 644-649.

Nuryatno, Y. J. (2012). Kualitas Layanan dan Positive Word of Mouth. Jurnal Dinamika Manajemen, 3(2), 148154.

Pandhega, S., Hati, S. R., \& Miranti, S. (2016). Pengaruh Persepsi Merk Jasa terhadap Service Quality, Value dan Loyalitas Pelanggan: Studi Industri Low Cost Airlines Indonesia. Jurnal MIX, 6(3), 349-366.

Paramita, M. S., Dania , W. A., \& Ikasari, D. M. (2015). Penilaian Kepuasan Konsumen terhadap Kualitas Pelayanan menggunakan Metode SERVQUAL dan SIX SIGMA (Studi Kasus pada Restoran Dahlia Pasuruan). Jurnal Industria, 4(3), 102-115.

Pasharibu, Y., Paramita, E. L., \& Febrianto, S. (2018). Price, Service Quality and Trust on Online Transportation Towards Customer Satisfaction. Jurnal Ekonomi dan Bisnis, 21(2), 240-264.

Pawirosumarto, S. (2016). Pengaruh Kualitas Sistem Kualitas Informasi dan Kualitas Layanan terhadap Kepuasan Pengguna Sistem E-Learning. Jurnal MIX, 6(3), 416-43.

Pawirosumarto, S., Katidjan, P. S., \& Mulyanto, A. D. (2015). Pengaruh Computer Self-Efficacy terhadap Kualitas Sistem, Kualitas Informasi Kualitas Layanan Pengguna, Kepuasan Pengguna dan Dampak Individu. Jurnal MIX, 6(2), 310-317.

Pradana, H. A., \& Sawitri, H. S. (2015). The Effects of Role Stressors and Emotional Satisfaction on Service Quality: Moderating Role of Gender. Jurnal Siasat Bisnis, 19(2), 161-169.

Pradani, E. A., Rohman, F., \& Siswanto. (2018). Effect of Patient-Centered Care on Service Quality and Satisfaction Level of BPJS Inpatients in Baptist Hospital Batu. Jurnal Aplikasi Manajemen, 16(1), 89100.

Prameswari, D., \& A, A. L. (2010). Pengaruh Kualitas Layanan Jasa terhadap Word of Mouth dengan Kepuasan Pelanggan sebagai Variael Antara (Studi pada Biro Perjalanan Umum Rosalia Indah Surabaya). Jurnal Bisnis dan Manajemen, 3(1), 49-65. 
Pratiwi, D., Wahyono, D., \& Sampurno. (2013). Analisis Kepuasan Pasien Farmasi Rawat Jalan Menggunakan Metode SERVQUAL: Studi Di Rumah Sakit Swasta X Jakarta. Jurnal Manajemen dan Pelayanan Farmasi, 3(1), 24-29.

Prihanto, A. (2013). Kepuasan dan Loyalitas Konsumen Korporat untk Acara Mice Terhadap Kualitas Pelayanan Hotel HSTH. Jurnal Manajemen dan Kewirausahaan, 15(2), 165-178.

Prihastono, E. (2012). Pengukuran Kepuasan Konsumen pada Kualitas Pelayanan Customer Service Berbasis web. Dinamika Teknik, 6(1), 14-24.

Purnama, A., \& Sailah, I. (2017). Peningkatan Tingkat Kepuasan DOsen Terhadap Kualitas Pelayanan Pelatihan Jurnal Berkualitas melalui Metode SERVQUAL. Jurnal Manajemen, 21(3), 418-433.

Puruwita, D. (2014). The Influence Cellular Provider Service Quality Towards Customer Loyalty Indosat in Jakarta. Jurnal Pendidikan Ekonomi dan Bisnis, 2(2), 3-62.

Puspitawati, N. M., \& Riana, I. G. (2014). Pengaruh Kepuasan Kerja terhadap Komitmen Organisasional dan Kualitas Layanan. Jurnal Manejemen Strategi Bisnis dan Kewirausahaan, 8(1), 68-80.

Putra, I. W. (2012). Pengaruh Kualitas Pelayanan terhadap Loyalitas Debitur Kredit Produktif (Studi Pada Kantor Cabang BNI SKC Malang). Jurnal Aplikasi Manajemen, 10(2), 437-449.

Puung, F. K., Fudholi, A., \& Dharmmesta, B. (2014). Analisis Pengaruh Kualitas Pelayanan Pada Kepuasan dan Loyalitas Pelanggan di Salon dan SPA. Jurnal Manajemen Pelayanan dan Farmasi, 4(2), 105-110.

Quita, A. G., \& Nugroho, S. S. (2019). The Effect of Online Service Quality and Consumers Motivation on Willingness to Participate in Co-Creation Activities. Jurnal Siasat Bisnis, 23(2), 113-126.

R, S. I. (2014). Analisis Pengaruh Kualitas Pelayanan terhadap Kepuasan Penyewa dalam Upaya Meningkatkan Loyalitas Penyewa (Studi Kasus PT. Grand Indonesia). Jurnal MIX, 4(1), 123-134.

R., A. P., Effendi, U., \& Effendi, M. (2015). Analisis Perencanaan Strategi Peningkatan Kualitas Pelayanan Konsumen dengan Metode Quality Function Deployment (QFD). Jurnal Industria, 4(1), 41-52.

Rahareng, V. J., \& Relawan, N. (2017). Pengaruh Kualitas Pelayanan Akademik terhadap Kepuasan Mahasiswa (Studi pada Mahasiswa Administrasi Bisnis Universitas Telkom). AdBispreneur, 2(2), 125-133.

Rahmawati, I. (2012). Pengaruh Kualitas Layanan terhadap Keputusan Pemilihan Tempat Pendidikan (Studi pada TK Raudlatul Jannah Pepelegi Waru-Sidoarjo). Jurnal Bisnis dan Manajemen, 5(1), 33-34.

Rahmawaty, A., \& Rokhman, W. (2018). The Role of Syariah Marketing in Increasing Customer Loyalty (An Empirical Study of BMT in Kudus Regency). IQTISHADIA, 11(2), 285-306.

Ramadania, Juniwati, \& Limanto, M. (2020). Interaksi E-Service Quality, Kesadaran Merek, Kepercayaan dan Kepuasan terhadap Minat pembelian Kembali dalam Transportasi On-Line Gojek. Jurnal Manajemen Strategi Bisnis dan Kewirausahaan, 14(2), 264-278.

Retnowati, N., Troena, A. E., Rahayu, M., \& Ismail, M. (2008). Pengaruh Kualitas Layanan, Orientasi Layanan, dan Strategi harga terhadap Kepuasan dan Loyalitas Pelanggan (Studi terhadap Pelanggan Jasa Transportasi Kereta Api Eksekutif). Jurnal Aplikasi Manajemen, 7(1), 134-150.

Rintar. (2011). Analisis Hubungan Kualitas Jasa Terhadap Kepuasan Konsumen Pada Lembaga Pendidikan Kejuruan. Jurnal Dinamika Manajemen, 2(1), 40-47.

Riorini, S. V., \& Widayati, C. C. (2014). Anteseden kan Konsekwensi dari Corporate Image pad Usaha Kecil Menengah/ UKM. Jurnal MIX, 4(3), 299-310.

Risal, T. (2019). Pengaruh Kualitas Pelayanan Terhadap Loyalitas Nasabah dengan Kepuasan sebagai Variabel Intervening pada BMT Kampoeng Syariah. JMB (Jurnal manajemen dan Bisnis), 1(1).

Rizan, M., \& Arrasyid, H. (2008). Analisis Asosiasi Merek, Nilai Produk, dan Kualitas Pelayanan Serta Pengaruhnya Terhadap Kepuasan dan Loyalitas Konsumen Sepeda Motor di Bekasi. Jurnal Siasat Bisnis, 12(2), 129-147.

Rokhman, W. (2016). Pengaruh Biaya, Angsuran dan Kualitas Pelayanan terhadap Kepuasan Nasabah Pembiayaan BMT di Kabupaten Kudus. IQTISHADIA, 9(2), 326-351.

Rusydi, M. K., \& Fathoni. (2011). Pengaruh Kualitas Pelayanan Terhadap Kepuasan Wajib Pajak Kendaraan Bermotor di Kota Batu. Jurnal Aplikasi Manajemen, 9(3), 990-999.

S.K, P., \& Pawirosumarto, S. (2017). Pengaruh Kualitas SIstem, Kualitas Informasi dan Kualiatas layanan terhadap PenggunaanSIstem E-Learning di Program Pascasarjana Universitas Mercu Buana. Jurnal Manajemen, 21(2), 282-305.

Salim, T. P., Rahayu, M., \& Sudjatno. (2019). Effect of the Service Quality on Tutoring Customers Word of Mouth and Satisfactiion in Malang City. Jurnal Aplikasi Manajemen, 17(3), 522-528.

Sancoko, B. (2010). Pengaruh Remunerasi terhadap Kualitas Pelayanan Publik. Bisnis \& Birokrasi, Jurnal Ilmiah Administrasi dan Organisasi, 17(1), 43-51.

Santoso, A., Kusnanto, H., \& Lazuardi, M. L. (2013). Analisis Kualitas Layanan Sistem Informasi Manajemen Farmasi Rumah Sakit Akademik Universitas Gadjah mada. Jurnal Manajemen dan Pelayanan Farmasi, 3(1), 58-63. 
Santoso, I. (2016). Peran Kualitas Produk dan Layanan Harga dan Atmosger Rumah Makan Cepat Saji terhadap Keputusan Pembelian dan Kepuasan Konsumen. Jurnal Manajemen Teknologi, 15(1), 94-109.

Santoso, W. K., Marchaban, \& Sudjaswadi, R. (2012). Analisis Tingkat Kepuasan Pasien Rawat Jalan Atas Kualitas Pelayanan Menggunakan Metode SERVQUAL. Jurnal Manajemen dan Pelayanan Farmasi, 2(3), 159163.

Sari, M., Prayogi, M. A., Jufrizen, \& Nasution, M. I. (2020). Membangun Loyalitas Pelanggan berbasis E-Service Quality dengan Mediasi Kepuasan Pelanggan (Studi pada Transportasi Grab-car di Kota Medan). Jurnal Manajemen Strategi Bisnis dan Kewirausahaan, 14(2), 218-235.

Sari, S. W., Sunaryo, \& Mugiono. (2018). The Effect of Service Quality on Customer Retention Through Commitment and Satisfavtion as Mediaton Variables in Java Eating House. Jurnal Aplikasi Manejemen, 16(4), 593-604.

Sari, Y. (2016). Pengaruh Kualitas Pelayanan dengan Kepuasan Konsumen Pada PT Pusri Palembang PPD Lampung. IKONOMIKA, 1(2), 196-208.

Sarmini, A. (2019). Kualitas Pelayanan Surat Izin Mengemudi (SIM) pada Kantor Satuan Lalu Lintas Polres Karimun. Sumatera Law Review, 246-257.

Sasongko, G. (2014). Analisis Pengaruh Citra Merek dan Kualitas Layanan Service Center terhadap Loyalitas Pelanggan Melalui Kepuasan Pelanggan. Jurnal MIX, 4(2), 270-285.

Sasongko, T. (2018). The Role of Employee Motivation on the Relationship Berween HRM Practices and Service Quality in Healthcare Organization. Jurnal Ilmiah Bidang Akuntansi dan Manajemen, 15(1), 1-11.

Sawitri, N. P., Yasa, N. N., \& Jawas , A. (2013). Pengaruh Kualitas Pelayanan terhadap Kepuasan dan Loyalitas Pelanggan Tegal Sari Accommodation di UBUD. Jurnal, 7(1), 41-47.

Septa , F., Yudhana, A., \& Fadlil, A. (2019). Analisis Kualitas Layanan e-Government dengan Pendekatan EGovQual Modifikasi. Jurnal Sistem Informasi Bisnis, 9, 157-164.

Setiadevi, S., Fahmi, I., \& Wibisono, Y. (2014). Kualitas Jasa Unit Pelaksana Teknis Pengujian Sertifikasi Mutu Barang-Lembaga Tembakau Jember. Jurnal Manajemen \& Agribisnis, 11(3), 144-153.

Setiawan, A., Munandar, J. M., \& Sarma, M. (2020). The Role of The Tourist Information Center (TIC) of Soekarno Hatta Airport in The Choice of Tourist Destinations Based on TOurist Characteristics and Services. Jurnal Aplikasi Manajemen, 18(4), 667-681.

Setiawati, L., \& Tjahjono, J. K. (2017). Pengaruh Service Standard Communication dan Komitmen Manajemen terhadap Kualitas Layanan dan Kepuasan Pelanggan. Jurnal MIX, 7(3), 363-386.

Setiyaningrum, A., \& Hidayat, H. (2016). Service Quality dan Kepuasan Konsumen: Studi Empiris dan Implikasinya pada Toko Online. Jurnal MIX, 6(2), 247-260.

Siahaan, S. M., Hakim , L., \& Hariyanti, T. (2018). The Effect of the Quality of Pharmaceutical Service on Outpatient Satisfaction on Amelia Hospital. Jurnal Aplikasi Manajemen, 16(1), 115-124.

Sintani, L. (2008). Komitmen Manajemen, Pemasaran Internal, Kepuasan Kerja Karyawan dan Perilaku Positif Karyawan dalam Mempengaruhi Kualitas Pelayanan Rumah Sakit (Studi pada Rumah Sakit Tipe B dan C di Kalimantan Tengah). Jurnal Aplikasi Manajemen, 7(4), 840-851.

Siregar, N. S. (2020). Komunikasi Terapeutik Tenaga Kesehatan terhadap Pasien Rawat Inap dalam Upaya Peningkatan Kualitas Pelayanan Rumah Sakit Haji Medan. Jurnal Inovasi, 17(1), 21-30.

Soebandhi, S., Wahid, A., \& Darmawanti, I. (2020). Service Quality and Store Atmosphere on Customer Satisfaction and Repurchase Intention. Jurnal Bisnis dan Manajemen, 13(1), 26-36.

Soegoto, E. S. (2017). Pengaruh Motivasi terhadap Pemberian Qualitas Pelayanan Desentralisasi di Indonesia. Jurnal Bisnis \& Manajemen, 18(2), 83-89.

Soelasih, Y., \& Sumani. (2019). Pembentuk Word of Mouth pada Perusahaan Penerbangan Bertarif Murah di Indonesia. Jurnal MIX, 9(3), 466-479.

Subroto, F. A. (2013). Pengaruh Market Orientation terhadap Service Quality, Satisfaction dan Loyalty Pelanggan Toko Buku Gramedia di Jawa Timur. Jurnal Manajemen dan Kewirausahaan, 15(1), 41-52.

Sudarma, K. (2012). Mencapai Sumber Daya Manusia Unggul (Analisis Kinerja dan Kualitas Pelayanan). Jurnal Dinamika Manajemen, 3(1), 76-83.

Sudiarditha, I. K., Saptono, A., \& Widyastuti, A. (2013). Pengaruh Pengetahuan Anggota Tentang Koperasi dan Kualitas Pelayanan terhadap Partisipasi Anggota pada Koperasi Serba Usaha (KSU) warga Sejahtera, Kelurahan Cipinang Jakarta Timur. Jurnal Pendidikan Ekonomi dan Bisnis, 1(1), 62-76.

Sugandi, A. (2013). Strategi Pemasaran dan Kualitas Pelayanan terhadap Profitabilitas Usaha Koperasi Produksi Susu Peternakan. Jurnal Aplikasi Manajemen, 11(4), 613-620.

Suharto. (2012). Pengaruh Service Quality terhadap Loyalitas Dimediasi Customer Value dan Cusstomer Trust (Studi pada Pengguna Jasa PT Pos Indonesia Persero Malang 56100). Jurnal Aplikasi Manajemen, 10(1), 199-215. 
Sukesi. (2011). Analisis Konsekuensi Kualitas Pelayanan terhadap Kepuasan Masyarakat (Kajian pada Pengguna Pelayanan PUblik DInas Perhubungan \& LLAJ Prov. Jawa Timur). Jurnal Manajemen dan Kewirausahaan, 13(1), 61-75.

Supadmi, N. L. (2009). Meningkatkan Kepatuhan Wajib Pajak Melalui Kualitas Pelayanan. Jurnal Ilmiah Akuntansi dan Bisnis, 4(2), 1-14.

Supariningsih, S. (2017). Kualitas Pelayanan Kepuasan Pasien Rumah Sakit: Kasus pada Pasien Rawat Jalan. Jurnal Medicoeticolegal dan Manajemen Rumah Sakit, 6(1), 9-15.

Suryani, T., Fauzi, A. A., \& Nurhadi, M. (2020). The Determinant of Website Quality and E-Service Quality at SME In Indonesia. Jurnal Manajemen dan Kewirausahaan, 22(2), 131-141.

Susanto, \& Iffah, R. (2012). Pengaruh Persepsi Produk Unggulan dan Kualitas Pelayanan terhadap Loyalitas Pasien Poliklinik Bedah di RSI PKU Muhammadiyah Pekajangan. Jurnal Medicoeticolegal dan Manajemen Rumah Sakit, 1(1), 1-12.

Sutomo, Najib, M., \& Djohar, S. (2017). Pengaruh Kualitas Pelayanan Lembaga Amil Zakat (LAZ) terhadap Kepusan dan Loyalitas Muzakki (Studi Kasus LAZ PKPU Yogyakarta). Jurnal Aplikasi Bisnis dan Manajemen, 3(1), 59-70.

Suwanda, S. A., \& Siregar, E. (2015). Analisis Kualitas Layanan terhadap Kepuasan Konsumen pada Braja Mustika Hotel \& Convention Centre, Bogor. Jurnal Manajemen, 19(4), 321-339.

Suwarni, A. T., Nugroho, A., \& Rahman, N. (2015). Implementasi Strategi Peningkatan Loyalitas Pelanggan melalui Corporate Brand Equity, Product Atribute dan Service Quality Studi kasus pada Perusahaan Distribusi Bahan Baku Bakery dan Pastry Untuk Wilayah Pemasaran Jakarta dan Bandung. Jurnal MIX, 5(1), 1-16.

Suyanto, \& Pratama, Y. H. (2018). Kepatuhan Wajib Pajak Orang Pribadi: Studi Aspek Pengetahuan, Kesadaran Kualitas Layanan dan Kebijakan Sunset Policy. Jurnal Ekonomi dan Bisnis, 21(1), 139-158.

Tampubolon, M., \& Sukmaningrum, P. (2007). Analisa Kepuasan Senior Market Terhadap Kualitas Layanan di Hotel Bintang 4 dan Bintang di Surabaya. Jurnal Manajemen dan Kewirausahaan, 9(2), 135-143.

Tanisah, \& Maftuhah, I. (2015). The Effects of Service Quality Customer Satisfaction Trust and Perceived Value Towards Customer Loyalty. Jurnal Dinamika Manajemen, 6(1), 55-61.

Tiza, M. F., \& Susanti, F. (2019). Pengaruh Kualitas Pelayanan terhadap Kepuasan Pelanggan, Studi Kasus pada Perusahaan JNE Cabang Padang.

Tj., H. W., \& Tanuraharjo, H. H. (2020). The Effect of Online Learning Service Quality on Student Satisfaction During COVIS-19 Pandemic in 2020. Jurnal Manajemen Indonesia, 20(3), 240-251.

Trisnadi, D. (2013). Pengaruh Kualitas Produk Tabungan dan Kualitas Layanan terhadap Minat Menabung Kembali di Cimb Niaga (Studi Kasus PT. Bank Cimb Niaga Tbk. Bintaro). Jurnal MIX, 3(3), 373-383.

Ubud, S. (2017). Customer Participation and Quality of Service in Improving Loyalty VIsitors in Tourism Park. Jurnal Aplikasi Manajemen, 15(3), 454-462.

Umam, S., Handayani, S. D., \& Aini, Q. (2014). Pengaruh Kualitas Jasa Pelayanan terhadap Citra Instalasi Radiologi di Rumah Sakit Gigi dan Mulut Pendidikan Univ. Muhammadiyah Yogyakarta. Jurnal Medicoeticolegal dan Manajemen Rumah Sakit, 3(2).

Wandebori, H., \& Wijaya, V. (2017). Consumer's Purchase Intention: Influencing Factors Unveiled at Korean Thematic Cafe (Case Study: Chingu Cafe). Jurnal Bisnis \& Manajamen, 18(2), 73-82.

Wantara, P. (2008). Pengaruh Citra, Reputasi dan Kualitas Pelayanan terhdap Kepuasan dan Loyalitas Mahasiswa PTS di Jawa Timur (Studi Pada STIE dengan Program Studi Terakreditasi). Jurnal Aplikasi Manajemen, $7(2), 326-334$.

Wardi, Y., Abror, \& Trinanda, O. (2018). The Marketing of Higher Education: Managing Student Loyalty Based on Tuition Fee Policy an Service Quality. Jurnal Bisnis \& Manajemen, 19(2), 101-108.

Wendha, A. A., Rahyuda, I. K., \& Suasana, I. G. (2013). Pengaruh Kualitas Layanan terhadap Kepuasan dan Loyalitas Pelanggan Garuda Indonesia di Denpasar. Jurnal Manajemen, Strategi Bisnis dan Kewirausahaan, 7(1), 19-28.

Wibowo, H. A. (2014). Moderasi Biaya Beralih pada Pengaruh Kualitas Layanan terhadap Kepuasan Pelanggan dan Kepuasan Pelanggan terhadap Loyalitas Pelanggan (Studi pada PTS X). Jurnal MIX, 4(3), 363-380.

Widiastuti, T., Aditya, E. M., \& Paranita, E. S. (2015). Peningkatan Kualitas Layanan Satu Pintu di Kota Semarang dengan Penerapan Hard Skill dan Soft Skill. Jurnal Aplikasi Manajemen, 13(3), 390-401.

Widyananto, I. H., \& Nurmahdi, A. (2014). Analisis Pengaruh Kualitas Produk, Distribusi dan Pelayanan Purna Jual terhadap Kepuasan Pelanggan Perusahaan Kemasan Plastik PT. Jayatama Selaras. Jurnal MIX, 4(3), 286-298.

Widyaningrum, K., \& Ahsan. (2017). Analysis of the Influence of Excellent Service Training on Inpatient Satisfaction in RSIA Puri Bunda Malang. Jurnal Aplikasi Manajemen, 15(2), 339-345.

Widyaningrum, N., Sampurno, \& Wahyono, D. (2013). Analisis Strategi Peningkatan Mutu Pelayanan Instalasi Farmasi Rumah Sakit. Jurnal Manajemen dan Pelayanan Farmasi, 3(2), 144-152.

http://mahesainstitute.web.id/ojs2/index.php/jehss

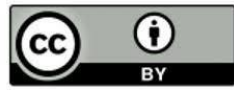

This work is licensed under a Creative Commons Attribution 4. 
Wijaya, A. F., Prastyari, C., \& Armanu. (2019). The Influence of Leadership Style on Service Quality in Higher Education: A Study at a Social Science Faculty. Jurnal Aplikasi Manajemen, 17(3), 426-433.

Wijaya, A. F., Surachman, \& Mugiono. (2020). The Effect of Service Quality, Perceived Value and Mediating Effect of Brand Image on Brand Trust. Jurnal Manajemen dan Kewirausahaan, 22(1), 45-56.

Wijaya, H., Beik, I. S., \& Sartono, B. (2017). Pengaruh Kualitas Layanan Perbankan terhadap Kepuasan dan Loyalitas Nasabah Bank Syariah XYZ di Jakarta. Jurnal Aplikasi Bisnis dan Manajemen, 3(3), 417-426.

Wilson, N. (2018). The Impact of Service Quality and Brand Image toward Customer Loyalty in the Indonesian Airlines Industry. Jurnal Manajemen Indonesia, 18(3), 222-234.

Yahya, M., Sapinah, \& Annas, S. (2014). Analisis Faktor-faktor yang Mempengaruhi Kualitas Pelayanan Karyawan Perusahaan Daerah Sulawesi Selatan. Jurnal Aplikasi Manajemen, 12(1), 90-98.

Yulianto, A. (2010). Meningkatkan Kualitas Pelayanan Jasa Penerbangan Indonesia Paska Insiden Kecelakaan Pesawat Terbang? Jurnal Dinamika Manajemen, 1(1), 1-8. 